\title{
The biophysics, ecology, and biogeochemistry of functionally diverse, vertically- and horizontally-heterogeneous ecosystems: the Ecosystem Demography Model, version 2.2 - Part 2: Model evaluation
}

Marcos Longo ${ }^{1,2,3}$, Ryan G. Knox ${ }^{4,5}$, Naomi M. Levine ${ }^{6}$, Abigail L. S. Swann ${ }^{7}$, David M. Medvigy ${ }^{8}$, Michael C. Dietze ${ }^{9}$, Yeonjoo Kim ${ }^{10}$, Ke Zhang ${ }^{11}$, Damien Bonal ${ }^{12}$, Benoit Burban ${ }^{13}$, Plínio B. Camargo ${ }^{14}$, Matthew N. Hayek ${ }^{1}$, Scott R. Saleska ${ }^{15}$, Rodrigo da Silva ${ }^{16}$, Rafael L. Bras ${ }^{17}$, Steven C. Wofsy ${ }^{1}$, and Paul R. Moorcroft ${ }^{1}$

${ }^{1}$ Harvard University, Cambridge, MA, United States

${ }^{2}$ Embrapa Agricultural Informatics, Campinas, SP, Brazil

${ }^{3}$ Jet Propulsion Laboratory, California Institute of Technology, Pasadena, CA, United States

${ }^{4}$ Massachusetts Institute of Technology, Cambridge, MA, United States

${ }^{5}$ Lawrence Berkeley National Laboratory, Berkeley, CA, United States

${ }^{6}$ University of Southern California, Los Angeles, CA, United States

${ }^{7}$ University of Washington, Seattle, WA, United States

${ }^{8}$ University of Notre Dame, Notre Dame, IN, United States

${ }^{9}$ Boston University, Boston, MA, United States

${ }^{10}$ Department of Civil and Environmental Engineering, Yonsei University, Seoul 03722, Republic of Korea

${ }^{11}$ Hohai University, Nanjing, Jiangsu, China

${ }^{12}$ INRA, UMR 1137 EEF, 54280, Champenoux, France

${ }^{13}$ INRA, UMR 0745 EcoFoG, Campus Agronomique, 97379, Kourou, France

${ }^{14}$ University of São Paulo, Piracicaba, SP, Brazil

${ }^{15}$ University of Arizona, Tucson, AZ, United States

${ }^{16}$ Federal University of Western Pará, Santarém, PA, Brazil

${ }^{17}$ Georgia Institute of Technology, Atlanta, GA, United States

Correspondence: M. Longo

(mlongo@post.harvard.edu)

Abstract. The Ecosystem Demography Model version 2.2 (ED-2.2) is a terrestrial biosphere model that simulates the biophysical and biogeochemical cycles of dynamic ecosystems while considering the role of vertical structure of plant communities and the heterogeneity of such structures across the landscape. In a companion paper, we described in detail how the model solves the energy, water, and carbon cycles, and verified the excellent conservation of such properties in long-term simulation.

5 Here, we present a thorough assessment of the model's ability to represent multiple processes associated with the biophysical and biogeochemical cycles, with focus on the Amazon forest. We used multiple measurements from eddy covariance towers, forest inventory plots and regional remote-sensing products to assess the model's ability to represent biophysical, physiological, and ecological processes at multiple time scales ranging from sub-daily to century-long. The ED-2.2 model accurately describes the vertical distribution of light, water fluxes and the storage of water, energy and carbon in the canopy air space, the regional distribution of biomass in tropical South America, and the variability of biomass as a function of environmental 
Geosci. Model Dev. Discuss., https://doi.org/10.5194/gmd-2019-71

Manuscript under review for journal Geosci. Model Dev.

Discussion started: 28 March 2019

(c) Author(s) 2019. CC BY 4.0 License.

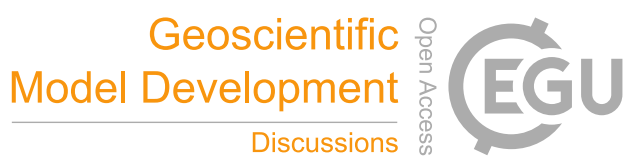

(c) (i)

drivers. In addition, ED-2.2 also simulates emerging properties of the ecosystem found in observations, such as the relationship between biomass and mortality rates and wood density, although the relationships predicted by the model were biased. We also identified some of the model limitations, such as the model's tendency to overestimate the magnitude and seasonality of heterotrophic respiration, and to overestimate growth rates in a nutrient-poor tropical site. The evaluation presented here highlights the potential of incorporating structural and functional heterogeneity within biomes in ESMs, to realistically represent the role of forest structure and composition on energy, water, and carbon cycles, as well as the priority areas for further model development.

\section{Introduction}

Terrestrial ecosystems are fundamental components of the earth system. Current estimates suggest that net terrestrial biosphere carbon uptake is near $3.2 \mathrm{GtC} \mathrm{yr}^{-1}$ (equivalent to $30 \%$ of fossil fuel carbon emissions), albeit this sink is partially offset by land use change (1.5 $\mathrm{GtC} \mathrm{yr}^{-1}$, or $16 \%$ of fossil fuel carbon emissions (Le Quéré et al., 2018). Climate change, land use change, and increase in atmospheric $\mathrm{CO}_{2}$ are likely to alter the ability of terrestrial ecosystems to accumulate carbon, yet the magnitude and even the persistence of terrestrial biosphere sink, as predicted by dynamic global vegetation models (DGVMs) remains highly uncertain (Friedlingstein et al., 2006, 2014; Krause et al., 2018). The response of tropical forests to global change is of particular interest, because these ecosystems store nearly $40 \%$ of the total terrestrial biomass (Erb et al., 2018), and their simulated response to climate change is strongly dominated by vegetation dynamics (Ahlström et al., 2015).

Most DGVMs have thorough and mechanistic representation of biophysical and biogeochemical cycles, and have greatly evolved over the past decades (Fisher et al., 2018). However, two important factors limit the ability of reducing the uncertainties of DGVMs. First, observations of key biophysical and ecological variables (e.g. forest inventory plots and eddy covariance towers) are not evenly distributed, and tropical ecosystems are considerably under-sampled (Schimel et al., 2015). Second, DGVMs tend to describe ecosystems based on very simple characteristics, often from average properties of the ecosystem as a whole, which precludes a proper representation of the heterogeneous environment in which individuals live. In reality, the dynamics of an ecosystem is the emerging property that integrates the contribution of a system of individuals with different strategies and ability to access resources needed for their growth, survival, and reproduction (Moorcroft, 2003, 2006; Evans, 2012; Fisher et al., 2018).

In a companion paper (Longo et al., 2019), we described the Ecosystem Demography Model version 2.2 (ED-2.2). Unlike most DGVMs, the ED-2.2 model is a terrestrial biosphere model that characterizes and represents the vertical and functional structure of plant communities, as well as the horizontal heterogeneity of terrestrial ecosystems. Importantly, ED-2.2 has complete biophysical and biogeochemical cores, which solve the energy, water, and carbon cycles at sub-daily resolution. The biophysical and biogeochemical cores build on previous model developments by other DGVMs; however, in ED-2.2, we also account for the local variability of structure and composition in plant communities.

In this paper, we present a detailed evaluation of the ED-2.2 model, with focus on the multiple processes that comprise the biophysical and biogeochemical cores. Formal optimization of model parameters was beyond the scope of this paper, although 
Geosci. Model Dev. Discuss., https://doi.org/10.5194/gmd-2019-71

Manuscript under review for journal Geosci. Model Dev.

Discussion started: 28 March 2019

(c) Author(s) 2019. CC BY 4.0 License.

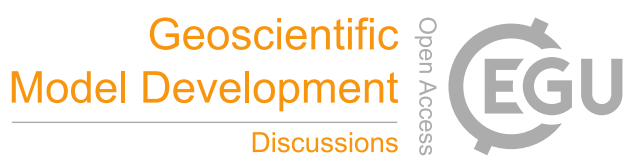

(c) (i)

it has been previously carried out with earlier versions of ED-2 (e.g. Medvigy et al., 2009; Kim et al., 2012; Fer et al., 2018). Instead, we focused on thoroughly evaluating the model in the Amazon, using two data-rich sites with decadal-long series of measurements that quantify several water, energy, and carbon components fluxes and storage terms predicted by ED-2.2. We also appraised the model ability to represent both the regional distribution of biomass and forest structure and the mechanisms that drive the variability in carbon stocks and structure, by comparing the model results with independent field measurements and remote-sensing estimates. Together, these analyses aim to verify the model consistency and the potential for the current model to be applied in both short-term and long-term studies.

\section{Methods}

\subsection{Assessment of short-term fluxes}

For most evaluations of biophysical and biogeochemical cycles, we ran ED-2.2 for two sites in the Amazon where both eddy flux towers and forest inventories were available for a long period: the Guyaflux tower $\left(5^{\circ} 17^{\prime} \mathrm{N} ; 52^{\circ} 55^{\prime} \mathrm{W}\right)$ at Paracou, French Guiana (GYF; Bonal et al., 2008), and the Tapajos National Forest site $\left(2^{\circ} 51^{\prime} \mathrm{S} ; 54^{\circ} 58^{\prime} \mathrm{W}\right)$, located in central Amazon (TNF; Hutyra et al., 2008; Pyle et al., 2008). Both data sets underwent multiple-stage quality control; in addition, variables used as input for ED-2.2 were gap filled, following Longo (2014). Net ecosystem productivity (NEE) was processed using the approach by Hayek et al. (2018), which corrects flux bias due to lack of turbulence and turbulent-independent divergence of $\mathrm{CO}_{2}$.

To ensure that model and observations at or near eddy covariance flux towers could be directly compared, and that the observed signal was strongly related to actual environment conditions, we aggregated the model results to polygon level hourly averages, and only used the model output for the time period when the each variable of interest was measured. Gross primary productivity (GPP) and ecosystem respiration $\left(\dot{R}_{\mathrm{Eco}}\right)$ are not measured but statistically modeled, therefore we compared all times in which the net ecosystem productivity (NEE) could be estimated from tower observations. We also required that the 24-hour period preceding any given time had less than 24 gap filled values among all seven driver variables.

To evaluate the in-canopy radiation profile, we compared model results against measured profiles of photosynthetically active radiation at two sites in the Brazilian Amazon: Jaru Biological Reserve (RJA: $10^{\circ} 05^{\prime} \mathrm{S} ; 61^{\circ} 56^{\prime} \mathrm{W}$ ) near Ji-Paraná, and Adolpho Ducke Forest Reserve (MDK: $2^{\circ} 57^{\prime} \mathrm{S}$; $59^{\circ} 55^{\prime} \mathrm{W}$ ), near Manaus (Cabral et al., 1996; Tomasella et al., 2008). At RJA, data were collected during two measurements campaigns in August-September 1992 and April-June 1993 and measurements were taken at 2.3, 6.1, 11.6, 15.7, 21.3, and $35.0 \mathrm{~m}$ above ground; at MDK, the measurement campaign occurred in August-September 1991 and sensors were installed at 5.0, 10.0, 15.0, 20.0, 25.0, and $35.0 \mathrm{~m}$ above ground; in both cases two to three sensors were installed in each level either East or West of the tower, and both sites used the same quantum radiation sensors of model SKP 215, skye Instruments Ltd, Powys, UK (Tomasella et al., 2008). To reduce the impact of the towers on the measurements, we only used data from sensors east of the towers in the morning and west of the towers in the afternoon (Mercado et al., 2007). The model was run for the same days of year as the data. However, we simulated different years - 1999-2006 for MDK and 1999-2002 for RJA — using the LBA-MIP data (de Gonçalves et al., 2013), because we did not have data from all 
Geosci. Model Dev. Discuss., https://doi.org/10.5194/gmd-2019-71

Manuscript under review for journal Geosci. Model Dev.

Discussion started: 28 March 2019

(c) Author(s) 2019. CC BY 4.0 License.

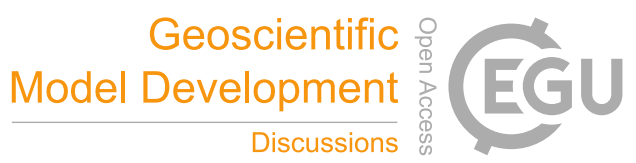

(c) (i)

meteorological variables needed by ED-2.2 during the period when the radiation profile data were collected. Also, because the diurnal cycle of any point measurement within the canopy depends on local heterogeneities can be dramatically affected by the Sun's azimuth and zenith angles (e.g. sun flecks when the sensor is aligned with an opening in the canopy), we only used the average daily radiation relative to the top of canopy to compare with the model results. The tree area index was estimated from published data at RJA (Simon et al., 2005) and near MDK (McWilliam et al., 1993).

\subsection{Evaluation of long-term dynamics}

To evaluate the model ability to represent the long-term dynamics, we carried out multiple simulations intended to test the model's ability to describe regional variability as well as the structural and functional diversity of ecosytems in tropical South America. First, to assess the model ability to represent the biome distributions in regional scale, we ran ED-2.2 starting from near-bare ground conditions and carried out a 500-year simulation across the Amazon ecoregion. We then resumed the simulation in 1900, applying anthropogenic disturbance and ran the model until 2002, using a combination of land use transition matrices from Hurtt et al. (2006), nudged to match the initial conditions from Soares-Filho et al. (2006) in the Amazon. We initialized soils with texture obtained from Quesada et al. (2011) for the Amazon, RADAMBRASIL (de Negreiros et al., 2009) for non-Amazonian areas of Brazil, and IGBP (Tempel et al., 1996) for non-Amazonian areas elsewhere, and the meteorological forcing from the Princeton University Global Meteorological Forcing Dataset (PGMF, Sheffield et al., 2006) for 1969 to 2008, which was recycled multiple times to simulate a period equivalent to 1500 through 2002.

To estimate the model sensitivity to light and water availability across the region, we used the annual average downwelling shortwave irradiance from the Clouds and the Earth's Radiant Energy System's Energy Balanced And Filled product (CERESEBAF; Kato et al., 2013) between 2001 and 2017, and the average of annual precipitation from the Tropical Rainfall Measurement Mission's (TRMM) Multi-Satellite Precipitation Analysis Product (TMPA-3B43 V7; TRMM, 2011; Liu et al., 2012) between 1998 and 2017. For maximum cumulative water deficit (MCWD, mm), we assumed a constant monthly evapotranspiration $\left(\mathrm{ET}_{0}=100 \mathrm{~mm} \mathrm{mo}^{-1}\right)$ and monthly precipitation $\left(P, \mathrm{~mm} \mathrm{month}^{-1}\right)$ from TMPA-3B43, following Malhi et al. (2009a). For any month $t$, we defined:

$\operatorname{MCWD}(t)=\min \left\{1200, \max \left[0, \operatorname{MCWD}(t-\Delta t)+\mathrm{ET}_{0}-P(t)\right]\right\}$

where $\Delta t=1$ month. The maximum of $1200 \mathrm{~mm}$ was imposed to avoid run-away water deficit at the most arid regions, where precipitation is never sufficient to bring water deficit back to zero because of the high baseline evapotranspiration. We reprojected the estimates of shortwave irradiance, precipitation, and water deficit to the same grid as ED-2.2 using spatial averaging. For each environmental variable, we divided the grid cells into 20 quantile-based groups $(0-0.05 ; 0.05-0.10 ; \ldots$; $0.95-1$ ), and obtained the average and the $90 \%$ quantile range within each bin for the ED-2.2 model and the three remotesensing estimates of aboveground biomass. To evaluate the model's ability to predict emergent properties, we used published values of biomass and mortality obtained from the RAINFOR field inventory network in the Amazon (Phillips et al., 2004; Baker et al., 2004a, b) and the results from long-term simulations near the field inventory sites (Levine et al., 2016). 
Geosci. Model Dev. Discuss., https://doi.org/10.5194/gmd-2019-71

Manuscript under review for journal Geosci. Model Dev.

Discussion started: 28 March 2019

(c) Author(s) 2019. CC BY 4.0 License.

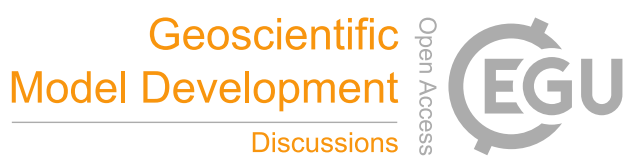

Finally, we tested both the forest structure predictions and the model's ability to represent variability of demographic rates at the two study sites (GYF and TNF) for which we had long-term forest inventory data. We ran the model from near-bare ground conditions for 500 years for each location, driven by the site-specific meteorological conditions, to obtain the near-steady state of each forest and to evaluate the forest structure predicted by the model at steady state. To evaluate the sensitivity of mortality and the growth rates, we carried out an ensemble of simulations using all combinations of (1) different initial times, between 5 and 60 years before the first inventory (intervals of 5 years); (2) soil texture, using clayey loam and sandy clay loam for GYF, and clayey sand and clay for TNF following the typical soils found at each site (Nepstad et al., 2002; Bonal et al., 2008); (3) assuming that trees were all evergreen or all drought deciduous. Only cohorts with $\mathrm{DBH} \geq 10 \mathrm{~cm}$ were considered for the comparison of structure and demographic rates, because this was the minimum size of trees measured at both locations (Pyle et al., 2008; Rowland et al., 2014).

\section{Results}

\subsection{Evaluation of energy and water fluxes}

Both GYF and TNF had measurements of outgoing shortwave radiation $\left(\dot{Q}_{\mathrm{SW}}^{\uparrow}\right)$ and outgoing photosynthetically active radiation $\left(\dot{Q}_{\mathrm{PAR}}^{\uparrow}\right)$. Here, we compared the outgoing radiation instead of net radiation because net radiation includes incoming radiation,

which are input variables for the model. The seasonal variation and the magnitude of both $\dot{Q}_{\mathrm{SW}}^{\uparrow}$ and $\dot{Q}_{\mathrm{PAR}}^{\uparrow}$ are close to observations at both sites: the bias in the annual average of $\dot{Q}_{\mathrm{SW}}^{\uparrow}$ was $3.0 \mathrm{~W} \mathrm{~m}^{-2}$ (GYF) and $0.6 \mathrm{~W} \mathrm{~m}^{-2}$ (TNF), and the annual average bias of $\dot{Q}_{\mathrm{PAR}}^{\uparrow}$ was $-0.9 \mu \mathrm{mol} \mathrm{m}{ }^{-2} \mathrm{~s}^{-1}$ (GYF) and $-1.6 \mu \mathrm{mol} \mathrm{m}{ }^{-2} \mathrm{~s}^{-1}$ (TNF) (Fig. 1a-d). Likewise, the vertical profiles of daily averages of relative incoming PAR are close to the simulations, especially considering the large uncertainties on the observed TAI profile and that the simulated years are not the same as the observations (Fig. 2a,b). When we only consider overcast hours (less sensitive to local horizontal heterogeneities), the model shows even better agreement with model predictions, particularly at RJA, where the average profile was measured at the same site as the original observations, albeit at different years. While limited by the observation constrains, this comparison suggests that the model is able to reasonably reproduce typical light profiles.

Compared to tower observations, the model predicted higher mean sensible heat flux at both sites. At GYF, ED-2.2 captures the seasonal cycle very similarly to the observations, however, the fluxes are on average $19.5 \mathrm{~W} \mathrm{~m}^{-2}$ higher in ED-2.2 than measured by the tower (Fig. 3a). On the other hand, the model predicts significantly higher values at TNF (average bias $35.9 \mathrm{~W} \mathrm{~m}^{-2}$ ), in particular during the dry season (average dry-season bias $44.5 \mathrm{~W} \mathrm{~m}^{-2}$ ). The predicted seasonal cycle at TNF is very similar to the model prediction for GYF, whereas the tower measurements suggest much less variation between wet and dry seasons (Fig. 3b). From the distribution of fluxes by time of the day, we found that ED-2.2 predicted higher than observed sensible fluxes during the afternoon at both sites (Fig. 3c,d). In addition, ED-2.2 was unable to capture events of strong nighttime negative flux as measured at both towers. The predicted canopy air space temperature at GYF is typically $0.5^{\circ} \mathrm{C}$ lower than tower estimates (Fig. S1a), whereas the predicted canopy air space temperate at TNF shows close agreement with tower estimates during the wet season, and ED-2.2 predicts temperatures about $0.5^{\circ} \mathrm{C}$ higher than tower estimates at TNF 
Geosci. Model Dev. Discuss., https://doi.org/10.5194/gmd-2019-71

Manuscript under review for journal Geosci. Model Dev.

Discussion started: 28 March 2019

(c) Author(s) 2019. CC BY 4.0 License.

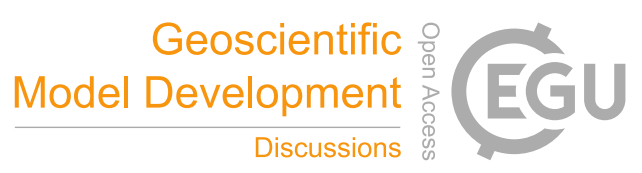

(c) (i)
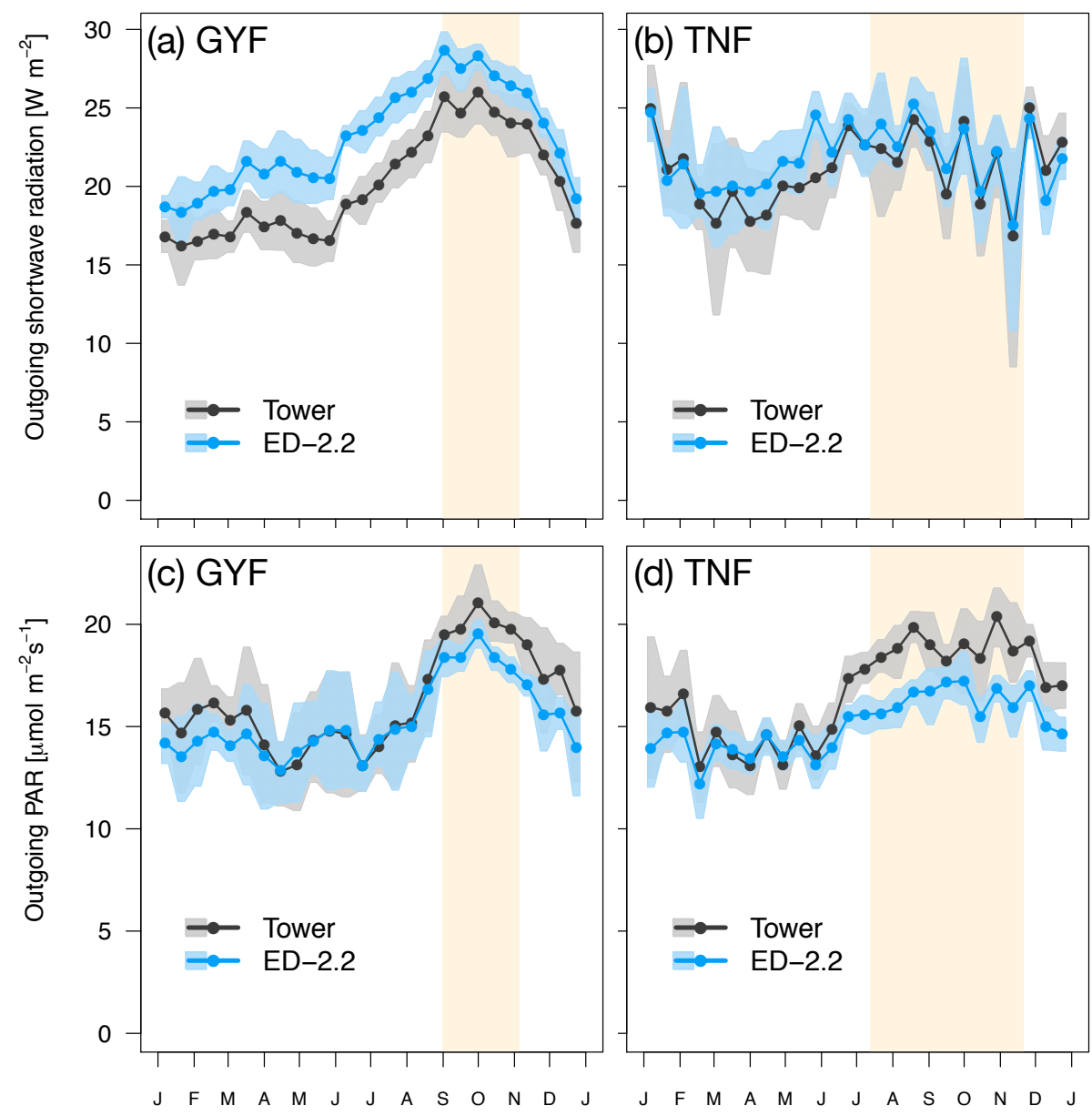

Figure 1. Mean annual cycle from fortnightly means of (a,b) outgoing shortwave radiation and (c,d) outgoing photosynthetically active radiation for (a,c) GYF and (b,d) TNF. Bands are the $95 \%$ confidence interval of means, and rectangles in the background correspond to the site's climatological dry season.

(Fig. S1b). Comparison with outgoing thermal infrared radiation, which is correlated with the vegetated surface temperature show that the model typically predicts higher-than-observed values at daily scale (Fig. S2a,b), as a result of the model predicting higher fluxes during the afternoon (Fig. S2c,d).

Water flux above canopy was well represented at both study sites (Fig. 4). The bias on annual average was $-0.23 \mathrm{~kg}_{\mathrm{W} \mathrm{m}}{ }^{-2} \mathrm{day}^{-1}$

5 for GYF and $+0.28 \mathrm{~kg}_{\mathrm{W} \mathrm{m}}^{-2} \mathrm{day}^{-1}$ for TNF. The agreement was even better during the dry season (bias $-0.12, \mathrm{~kg}_{\mathrm{W} \mathrm{m}} \mathrm{m}^{-2} \mathrm{day}^{-1}$ for GYF and $+0.12 \mathrm{kgW} \mathrm{m}^{-2}$ day $^{-1}$ for TNF). ED-2.2 correctly represents increased water flux during the dry season in TNF (Fig. 4b), and that water flux does not increase during the dry season in GYF (Fig. 4a), although the model underestimates the fluxes during the first wet season (Dec-Feb) in GYF. Likewise, the diurnal cycle of water flux is well characterized at both sites, with median values predicted by the model similar to observations both during the day and during the night (Fig. 4c,d). 
Geosci. Model Dev. Discuss., https://doi.org/10.5194/gmd-2019-71

Manuscript under review for journal Geosci. Model Dev.

Discussion started: 28 March 2019

(c) Author(s) 2019. CC BY 4.0 License.
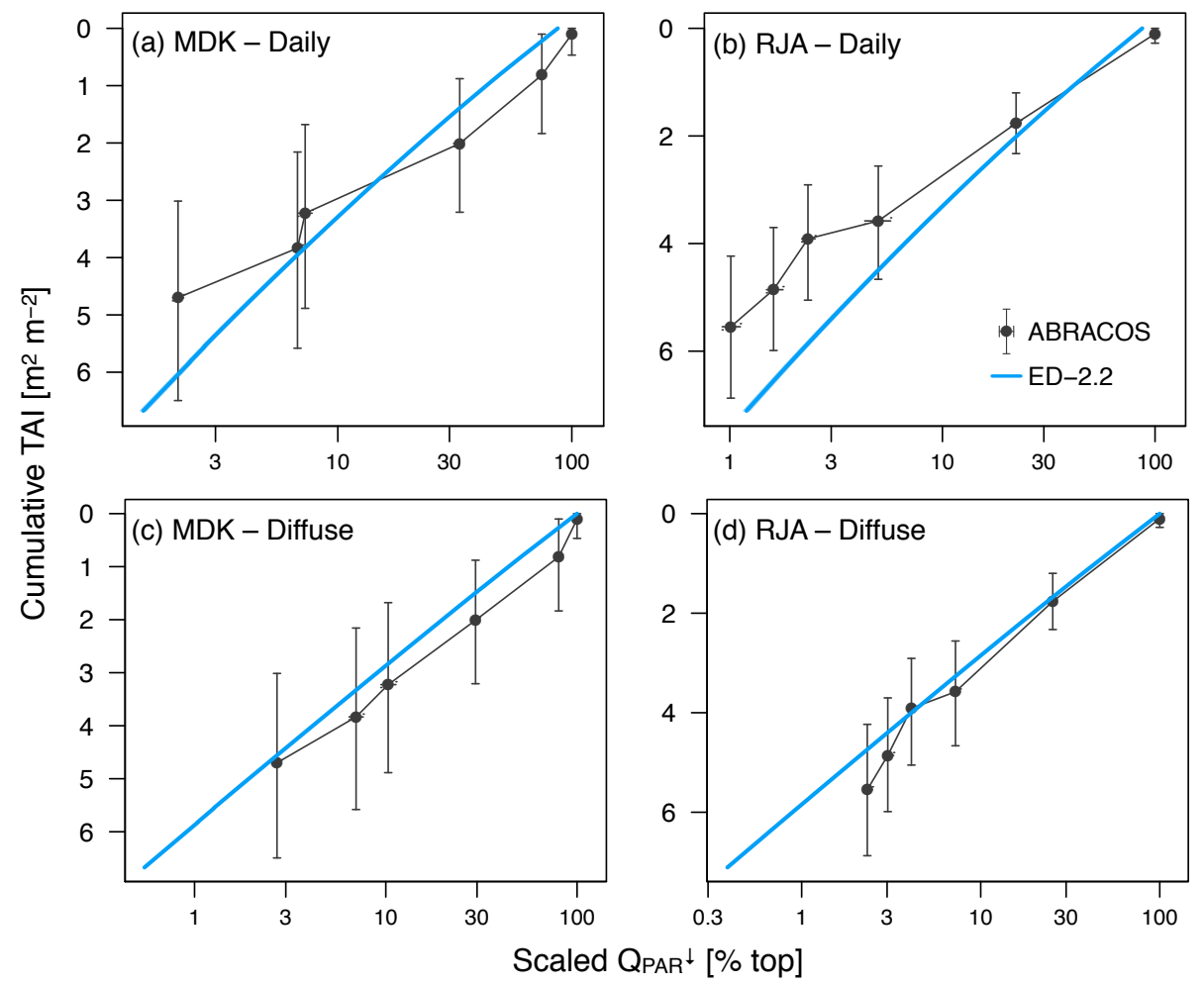

Figure 2. Comparison of downward photosynthetically active radiation relative to the top of canopy. (a,b) Average of daily accumulation; $(\mathrm{c}, \mathrm{d})$ average of times with diffuse radiation only for (a,c) Adolpho Ducke (MDK) and (b,d) Jaru (RJA). Shaded areas in the model correspond to the $95 \%$ confidence interval, using simple bootstrap of the daily and diffuse hour subsamples, respectively. Horizontal whiskers in observed values also correspond to the $95 \%$ confidence interval of daily and diffuse subsamples, whereas the vertical whiskers correspond to the interval on leaf area index.

The mean canopy air space humidity at GYF shows excellent agreement during the wet season and slight underestimation during the dry season (Fig. S1d). In contrast, the model predictions at TNF show slightly lower values during the wet season, consistent with higher water fluxes, and agrees well during the dry season (Fig. S1d).

\subsection{Evaluation of productivity and respiration}

5 When we compared gross primary productivity (GPP) with estimates from eddy covariance towers, the model captured the weak seasonality with slightly higher values during the dry season at GYF although the magnitude was consistently lower (Fig. 5a), whereas it captured the magnitude of GPP at TNF but it could not represent the decreased GPP early in the dry season (Fig. 5b).

Ecosystem respiration from ED-2.2 is more seasonal than the tower estimates, and the model predicts the highest respiration rates during the wet season at both sites, whereas tower-based estimates do not show a consistent seasonal pattern. Based on 
Geosci. Model Dev. Discuss., https://doi.org/10.5194/gmd-2019-71

Manuscript under review for journal Geosci. Model Dev.

Discussion started: 28 March 2019

(c) Author(s) 2019. CC BY 4.0 License.

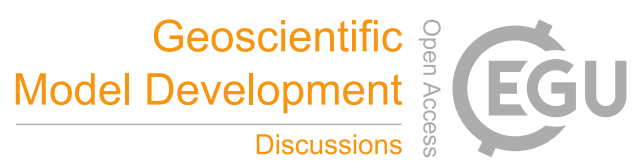

(c) $($ )
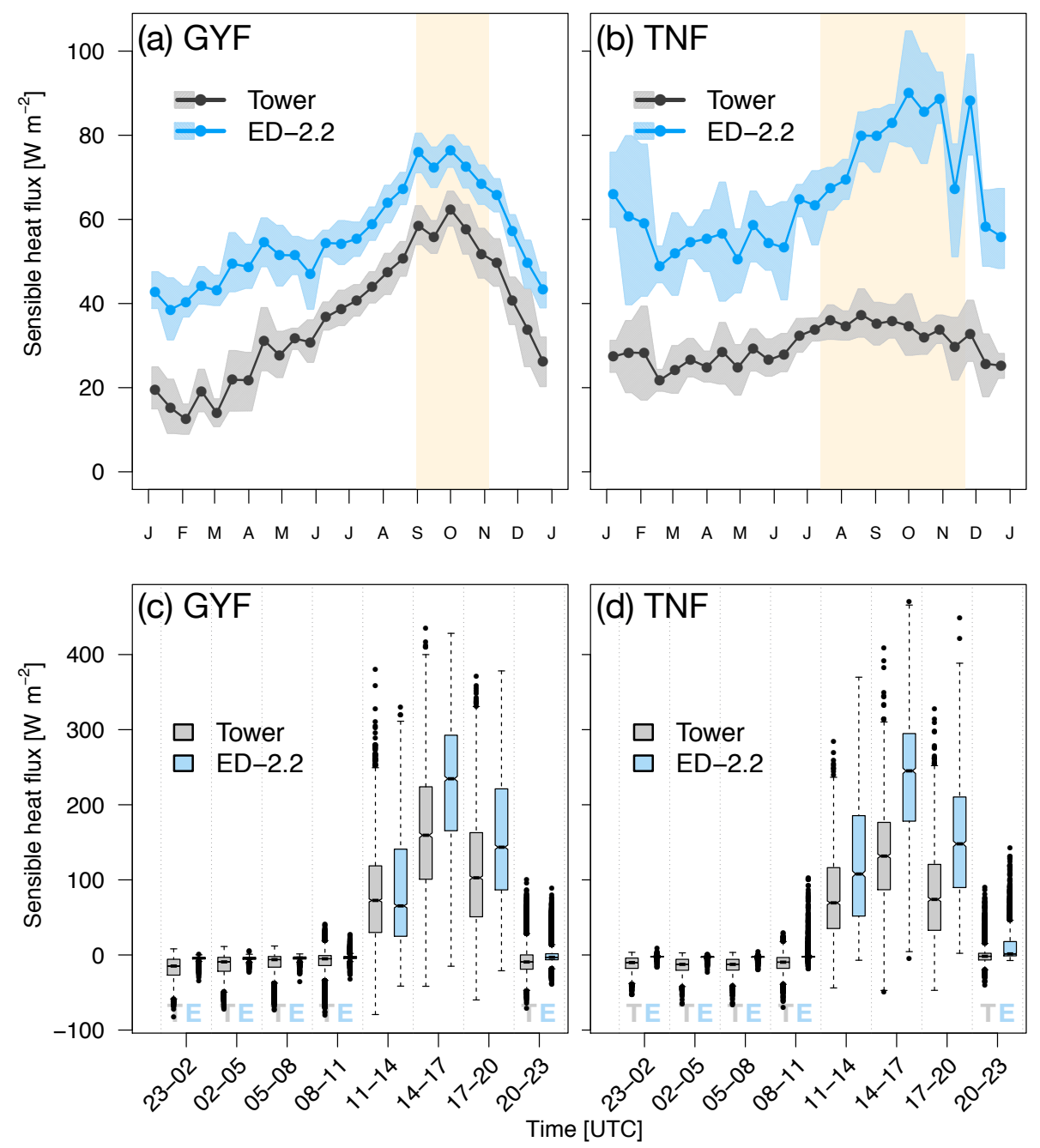

Figure 3. Mean annual cycle from fortnightly means of sensible heat flux for (a) GYF and (b) TNF. Bands are the $95 \%$ confidence interval of means, and rectangles in the background correspond to the site's climatological dry season. Box plot of sensible heat fluxes aggregated by time of day for all hours with available data for (c) GYF and (d) TNF.

tower estimates, respiration reaches the maximum early in the dry season in GYF (Fig. 6a), whereas the maximum occurs during the wet season in TNF (Fig. 6b). At both sites the model response is largely driven by fluctuations in soil moisture affecting heterotrophic respiration (Fig. 6c,d).

Ecosystem respiration is not directly measured from eddy covariance tower. The magnitude of ecosystem respiration from

5 towers often depend on the choice of the $u^{\star}$ filter (Hayek et al., 2018), and can be biased because the extrapolation of respiration from nighttime to daytime does not account the light inhibition of daytime leaf respiration known as the Kok effect (Wehr et al., 2016). Therefore, we also compared the model results against results from other studies that focused on measuring or estimating 
Geosci. Model Dev. Discuss., https://doi.org/10.5194/gmd-2019-71

Manuscript under review for journal Geosci. Model Dev.

Discussion started: 28 March 2019

(c) Author(s) 2019. CC BY 4.0 License.

(c) (i)
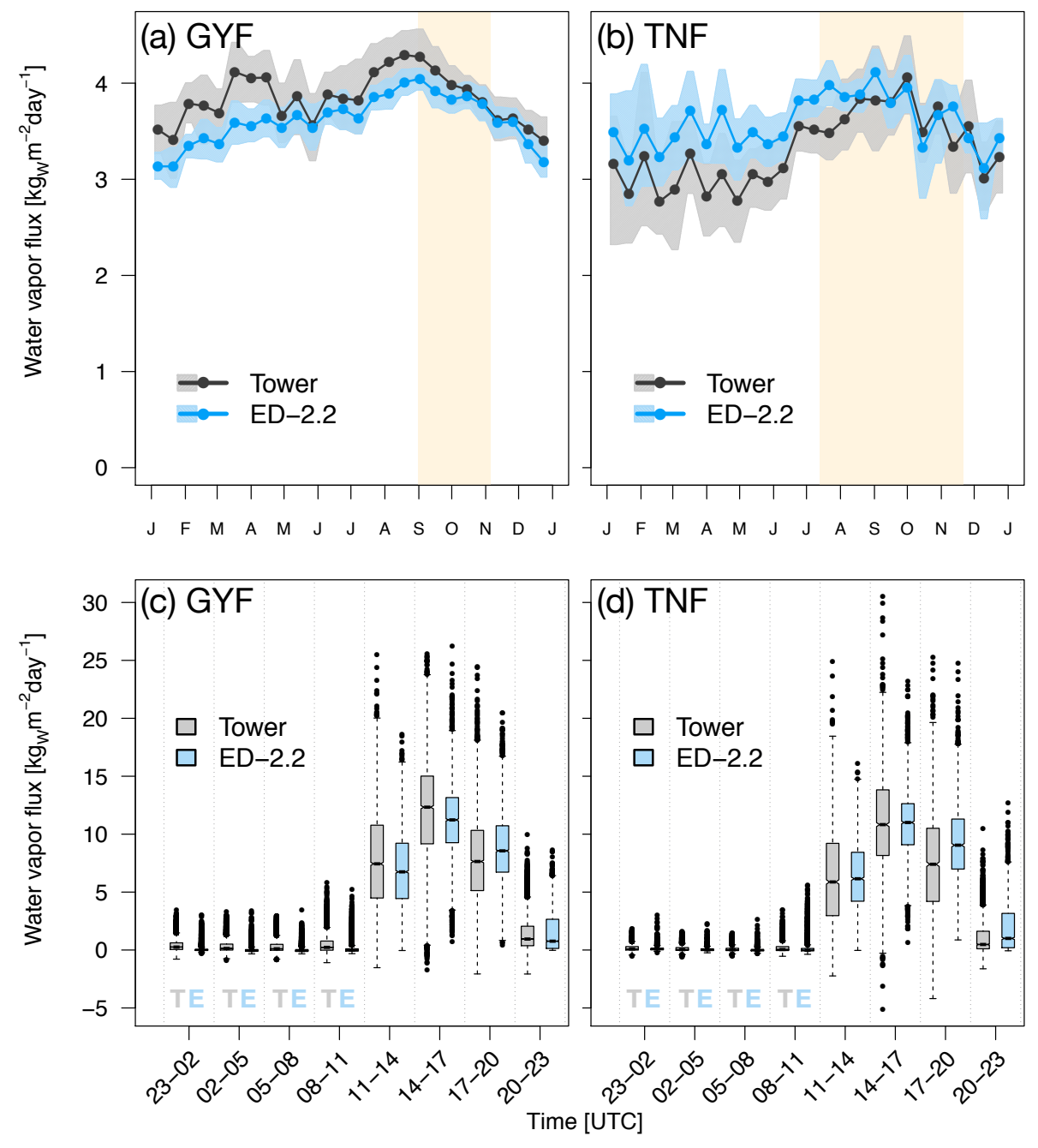

Figure 4. Mean annual cycle from fortnightly means of water flux for (a) GYF and (b) TNF. Bands are the 95\% confidence interval of means, and rectangles in the background correspond to the site's climatological dry season. Box plot of water fluxes aggregated by time of day for all hours with available data for (c) GYF and (d) TNF.

each component of the total respiration. For TNF, we used the respiration components estimated by a bottom-up assessment of the carbon cycle (Malhi et al., 2009b). For GYF, we estimated the respiration terms using previously published results and aggregated the components following Malhi et al. (2009b) (Supplement S1). The mean ecosystem respiration predicted by ED-2.2 overlaps with the $95 \%$ confidence interval at both sites (Table 1). In GYF, differences in heterotrophic respiration are the largest and explain most of the difference in the total respiration, whereas in TNF the positive bias in total respiration is due to autotrophic respiration. Within the autotrophic respiration, ED-2.2 predicts stem respiration that is $89-134 \%$ higher than the bottom-up assessment. In GYF the excessive stem respiration is compensated by leaf and root respiration that are $36 \%$ 
Geosci. Model Dev. Discuss., https://doi.org/10.5194/gmd-2019-71

Manuscript under review for journal Geosci. Model Dev.

Discussion started: 28 March 2019

(c) Author(s) 2019. CC BY 4.0 License.

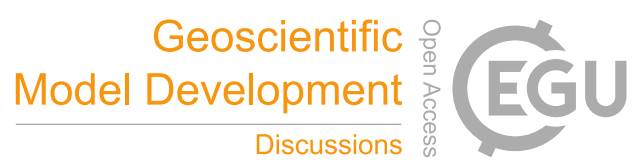

(c) (i)
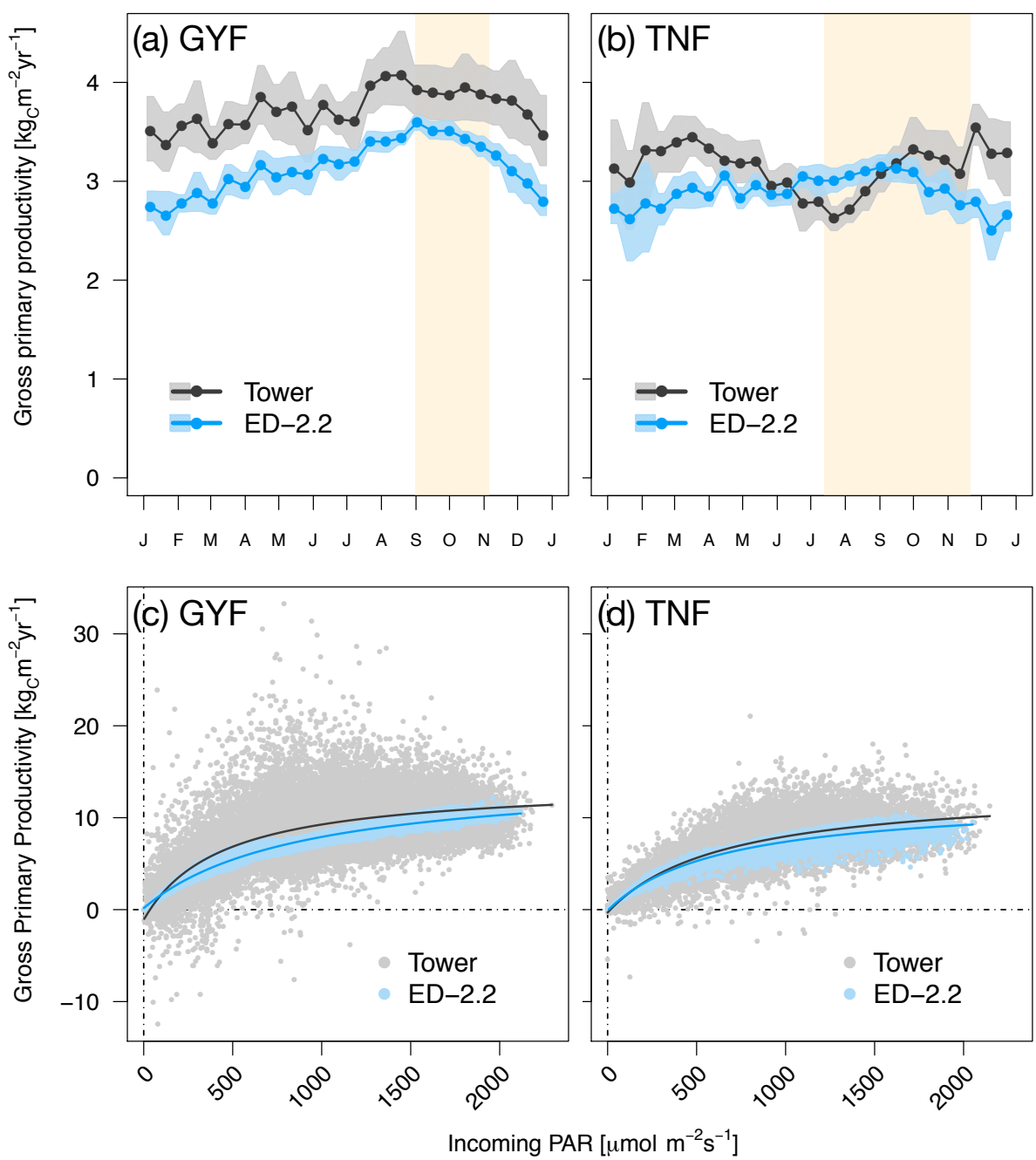

Figure 5. Mean annual cycle from fortnightly means of GPP for (a) GYF and (b) TNF. Bands are the $95 \%$ confidence interval of means, and rectangles in the background correspond to the site's climatological dry season. Hourly averages of GPP as a function of incoming PAR for both model and tower based estimates at (c) GYF and (d) TNF.

and $19 \%$ lower than field estimates, respectively. As a result, the total autotrophic respiration at GYF is within one standard error from the expected rate based on the bottom-up analysis. In TNF, the reference leaf and root respiration are nearly half the magnitude for GYF, and as a result, ED-2.2 autotrophic respiration is $57 \%$ higher than the estimates by Malhi et al. (2009b).

\subsection{Regional patterns of biomass}

5 The model correctly predicts the extension of the Amazon forest (Fig. 7a), and it also represents the regional distribution of aboveground biomass within the Amazon biome compared to regional biomass maps from Saatchi et al. (2011), Baccini et al. 
Geosci. Model Dev. Discuss., https://doi.org/10.5194/gmd-2019-71

Manuscript under review for journal Geosci. Model Dev.

Discussion started: 28 March 2019

(c) Author(s) 2019. CC BY 4.0 License.

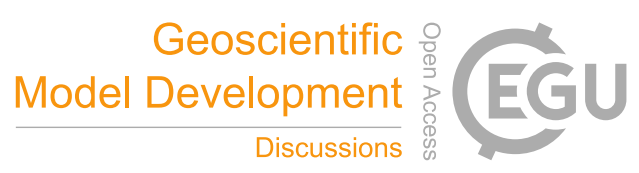

(c) (i)
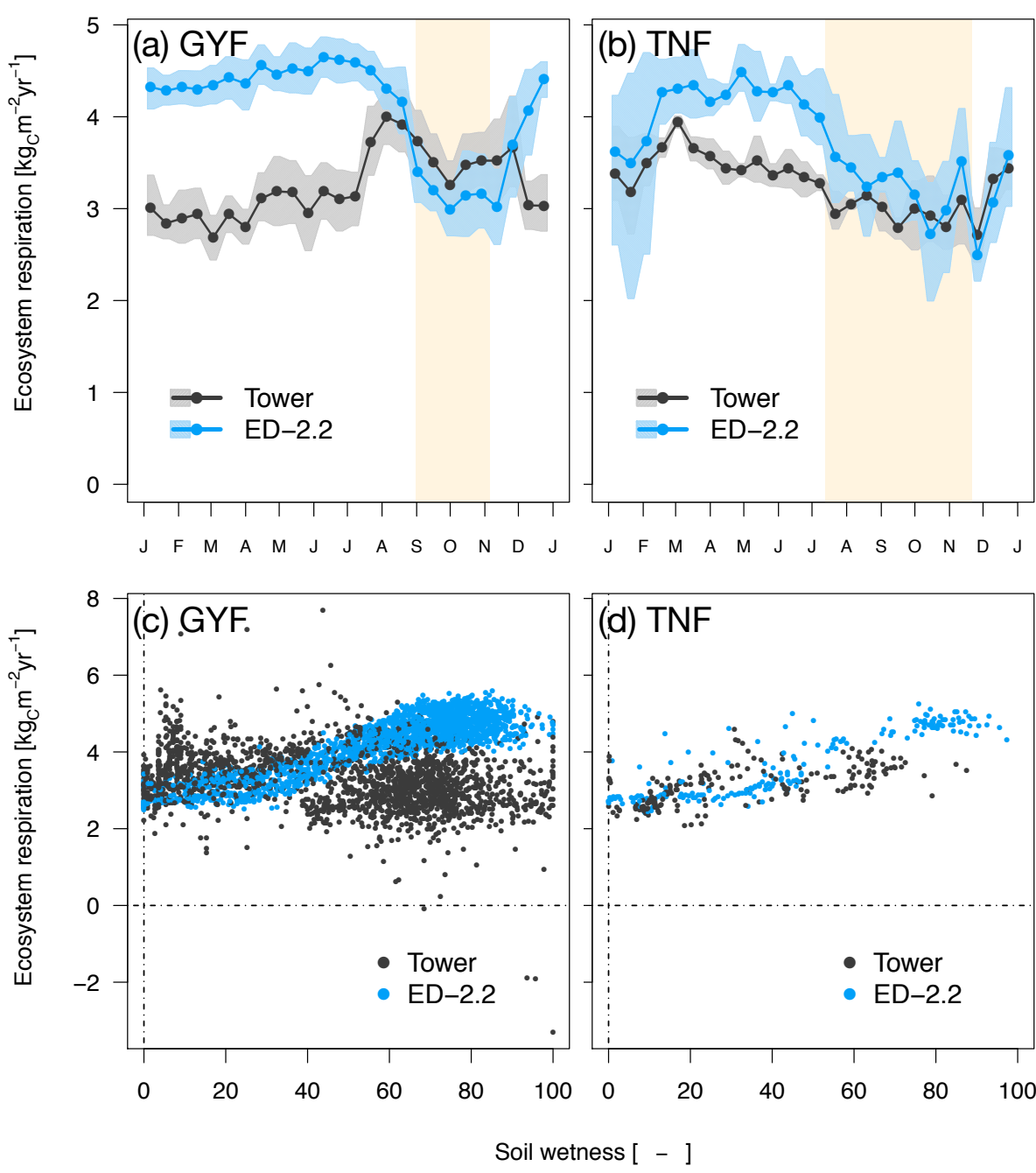

Figure 6. Mean annual cycle from fortnightly means of ecosystem respiration for (a) GYF and (b) TNF. Bands are the $95 \%$ confidence interval of means, and rectangles in the background correspond to the site's climatological dry season. Daily mean ecosystem respiration for (c) GYF and (d) TNF as a function of daily mean relative soil moisture at (c) $20 \mathrm{~cm}$ and (d) $50 \mathrm{~cm}$, for days with both soil moisture measurements and tower-based estimates of ecosystem respiration.

(2012) and Avitabile et al. (2016), the latter being based on the other two maps. For example, ED-2.2 predicts higher aboveground biomass in the Guiana Shield, similar to estimates from Saatchi et al. (2011) and Avitabile et al. (2016) (Fig. 7b,d), the higher biomass near the border between Brazil, Peru, and Colombia, similar to Baccini et al. (2012) and Avitabile et al. (2016) (Fig. 7c,d), and the low biomass, open savanna area near the Brazil-Guyana-Venezuela border. The model generally predicts 5 higher biomass than the three remote-sensing maps for most of the Amazon south of the Guiana Shield, particularly in the Western part of the Amazon (Fig. S3b-d), resulting in a peak in the distribution of biomass at $16.5 \mathrm{kgC} \mathrm{m}^{-2}$, whereas the highbiomass peaks ranged between $11.5-14.0 \mathrm{kgC} \mathrm{m}^{-2}$ for the remotely sensed estimates of aboveground biomass (Fig. 8a). The 
Geosci. Model Dev. Discuss., https://doi.org/10.5194/gmd-2019-71

Manuscript under review for journal Geosci. Model Dev.

Discussion started: 28 March 2019

(c) Author(s) 2019. CC BY 4.0 License.

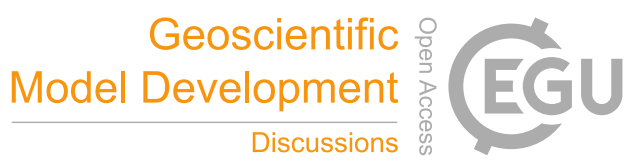

Table 1. Comparison of respiration between ED-2.2 and published values for GYF and TNF ( $\bar{X} \pm \mathrm{SE}(\bar{X})$ for any variable $X)$, using a bottom-up approach with published values. Values in parentheses are the standard error of the mean. For ED-2.2 the standard error was estimated from bootstrapping the annual means.

\begin{tabular}{lcccc}
\hline & \multicolumn{2}{c}{ Paracou $(\mathrm{GYF})^{a}$} & \multicolumn{2}{c}{ Tapajós (TNF) $^{b}$} \\
& Bottom-up estimates & ED-2.2 & Bottom-up estimates & ED-2.2 \\
\hline Ecosystem & $3.8 \pm 0.5$ & $4.03 \pm 0.12$ & $3.0 \pm 0.4$ & $3.80 \pm 0.10$ \\
Heterotrophic & $1.10 \pm 0.20$ & $1.66 \pm 0.03$ & $1.49 \pm 0.14$ & $1.432 \pm 0.024$ \\
Autotrophic & $2.8 \pm 0.5$ & $2.37 \pm 0.10$ & $1.5 \pm 0.4$ & $2.36 \pm 0.09$ \\
Soil+CWD & $1.84 \pm 0.23$ & $2.20 \pm 0.05$ & $1.65 \pm 0.13$ & $1.97 \pm 0.04$ \\
Leaf & $1.4 \pm 0.4$ & $0.896 \pm 0.004$ & $0.7 \pm 0.4$ & $0.937 \pm 0.005$ \\
Stem & $0.504 \pm 0.019$ & $0.94 \pm 0.07$ & $0.38 \pm 0.10$ & $0.89 \pm 0.06$ \\
Root & $0.67 \pm 0.20$ & $0.542 \pm 0.030$ & $0.37 \pm 0.08$ & $0.534 \pm 0.026$ \\
\hline${ }^{a}$ Observed values for GYF are summarized in Supplement S1. Estimates were based on the approach described by Malhi et al. (2009b, c). \\
${ }^{b}$ Observed values for TNF are from Malhi et al. (2009b, c) and references therein. \\
${ }^{c}$ ED-2.2 does not have a separate coarse woody debris pool, therefore we compared the sum of both.
\end{tabular}

ED-2.2 model and the remote-sensing estimates consistently predict relatively lower density function for intermediate values of biomass, and a pronounced peak of low biomass, even though the low-biomass peak predicted by ED-2.2 $\left(0.65 \mathrm{kgC} \mathrm{m}^{-2}\right)$ is lower than the remote-sensing estimates $\left(1.0-3.4 \mathrm{kgC}, \mathrm{m}^{-2}\right.$, Fig. $\left.8 \mathrm{a}\right)$. The shift in the low-biomass peak is mostly driven by ED-2.2 predictions of biomass in the savannas and xeric shrublands of Eastern Brazil, which were consistently lower than the remote-sensing estimates (Fig. S3). We also compared the results of leaf area index (LAI) with estimates from the Moderate Resolution Imaging Spectroradiometer (MODIS, product MCD15A2H, Collection 6) (Yan et al., 2016) and found that ED-2.2 predicted a similar extent of LAI over the Amazon region (Fig. S4). However, ED-2.2 predicted lower LAI than MODIS for most of the Amazon, in particular along the arc of deforestation, and higher LAI in northwestern Colombia and Central Brazil (Fig. S4c).

The predicted spatial variability of total carbon stocks in the region emerged from variation in the environmental conditions such as variability in available light and water (Fig. 8). Both ED-2.2 and the three remote-sensing biomass consistently showed the highest average biomass $\left(11.7-15.1 \mathrm{kgC} \mathrm{m}^{-2}\right)$ at $195 \mathrm{~W} \mathrm{~m}^{-2}$, and the sharpest decline as a function of increased irradiance $\left(0.53-0.77 \mathrm{~kg}_{\mathrm{C}} \mathrm{W}^{-1}\right.$ ) near $225 \mathrm{~W} \mathrm{~m}^{-2}$ (Fig. 8b). Similarly, the relationship between annual precipitation and above-ground biomass was consistent between model and remote-sensing estimates, with the highest changes in average biomass by increase in annual rainfall occurring between 1500 and $2200 \mathrm{~mm} \mathrm{yr}^{-1}$, and relatively stable values of above-ground biomass above $2500 \mathrm{~mm}$ (Fig. 8c). The increasing dry season severity, summarized by MCWD, has a strong association with decreasing average aboveground biomass in both the model and the remote-sensing estimates when the annual MCWD is less than $500 \mathrm{~mm}$. The strongest declines in average biomass occurred at mean annual MCWD between $300-350 \mathrm{~mm}$ in both ED-2.2 and the remote-sensing estimates (Fig. 8d). It must be noted, however, that the transition between high biomass and low biomass when 
Geosci. Model Dev. Discuss., https://doi.org/10.5194/gmd-2019-71

Manuscript under review for journal Geosci. Model Dev.

Discussion started: 28 March 2019

(c) Author(s) 2019. CC BY 4.0 License.

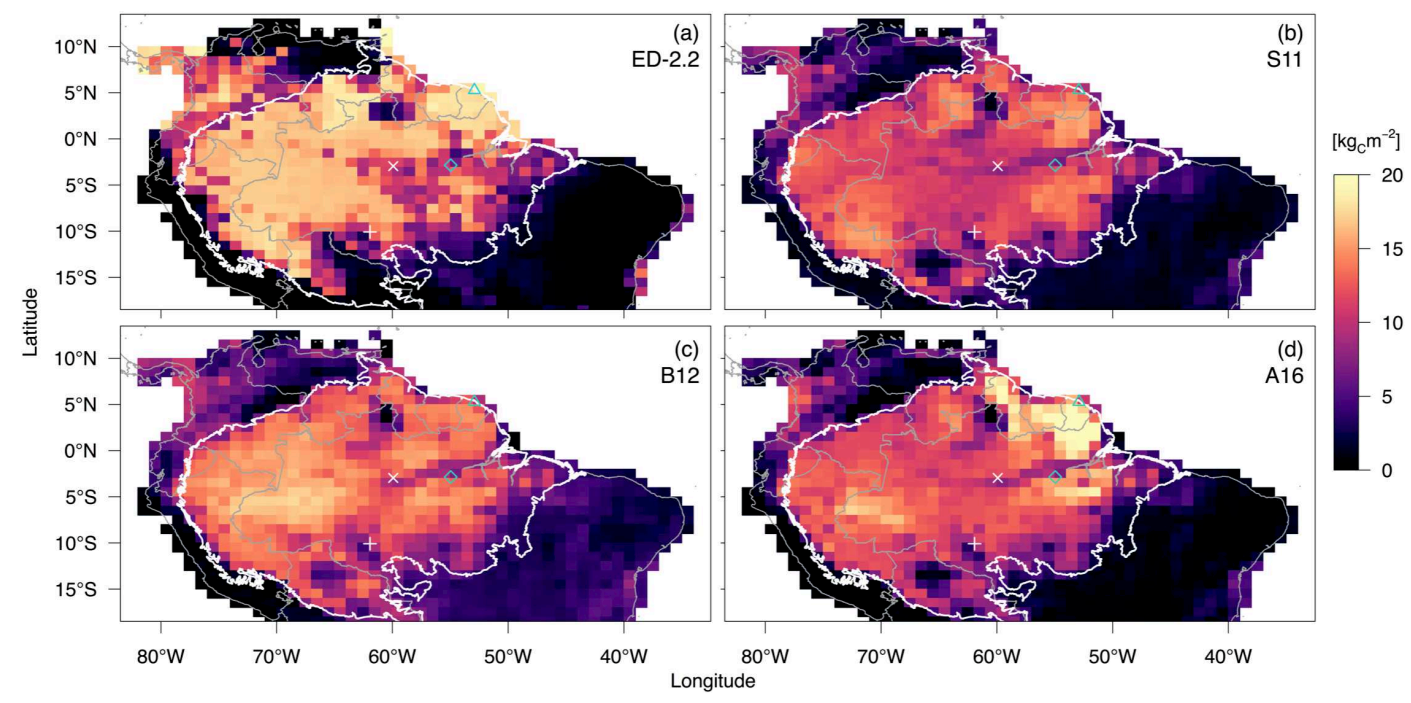

Figure 7. Comparison of aboveground biomass from (a) ED-2.2 and based on remote-sensing estimates from (b) Saatchi et al. (2011), (c) Baccini et al. (2012), and (d) Avitabile et al. (2016). Remote-sensing maps were aggregated to $1^{\circ}$ resolution. Blue points represent the focus sites of Paracou (GYF, triangle) and Tapajós (TNF, lozenge). White points represent the sites used for radiation profile evaluation: Ducke $(\mathrm{MDK}, \times)$, and Jaru (RJA, + ). White contour is the domain of the Amazon biome, and grey contours are the political borders. Maps of the differences between ED-2.2 and remote-sensing are shown in Fig. S3.

MCWD $300-350 \mathrm{~mm}$ is substantially more pronounced in ED-2.2 $\left(-0.075 \mathrm{kgC} \mathrm{m}^{-2} \mathrm{~mm}^{-1}\right)$ than in the remote-sensing estimates (between -0.041 and $-0.050 \mathrm{kgC} \mathrm{m}^{-2} \mathrm{~mm}^{-1}$ ) (Fig. 8d).

\subsection{Assessment of forest function and structure}

In addition to the total carbon stocks, the regional variability in forest function and composition at steady state is generally well characterized by ED-2.2. First, the range and the variability of biomass across the network is generally well characterized, with the exception of the driest sites located in Bolivia (red dots in Fig. 9a), where the model predicts less biomass than observations because of frequent fires predicted in the model. Also, both the model and the field measurements show similar negative correlation between biomass and mortality rates (Fig. 9b), and a similar positive correlation between biomass and the mean wood density (Fig. 9c), albeit significant differences exist in biomass for any given value of mortality or wood density (Fig. 9b,c). Both wood density and mortality rates are related to the abundance of pioneers or late successional individuals both in the model (Moorcroft et al., 2001) and in observations (e.g. Chave et al., 2009; Kraft et al., 2010), suggesting that the model characterizes the variability in forest composition within the Amazon region.

The model captured the general distribution slope of stem demographic density (abundance) at GYF (Fig. 10a), and both the total basal area and the typical distribution of basal area for individuals with DBH between 20 and $50 \mathrm{~cm}$ (Fig. 10b), although the model predicted a lower contribution from trees with $\mathrm{DBH}<20 \mathrm{~cm}$ to both abundance and basal area, and a 
Geosci. Model Dev. Discuss., https://doi.org/10.5194/gmd-2019-71

Manuscript under review for journal Geosci. Model Dev.

Discussion started: 28 March 2019

(c) Author(s) 2019. CC BY 4.0 License.

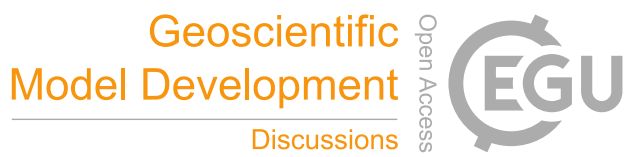

(c) (i)
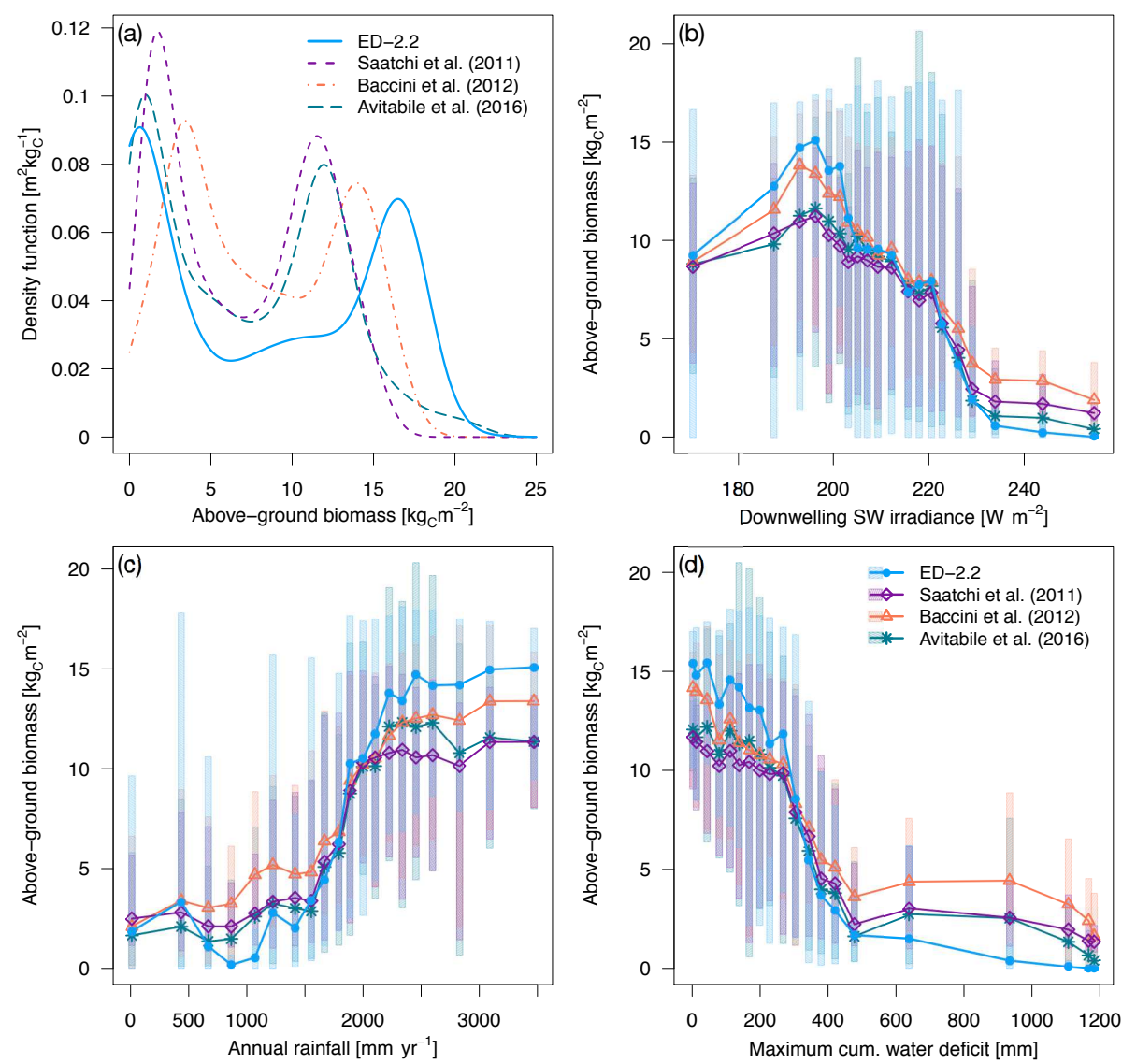

Figure 8. (a) Density functions of aboveground biomass predicted by ED-2.2 and based on remote-sensing estimates from Saatchi et al. (2011), Baccini et al. (2012), and Avitabile et al. (2016); points used to derive the distribution are the same as Fig. 7, and the density functions were calculated using the same bin width across the range of biomass from the model and the remote-sensing based maps. (b-d) Average biomass predicted by ED-2.2 and based on remote-sensing maps, aggregated by annual averages of (b) downwelling shortwave irradiance; (c) mean annual precipitation; (d) maximum cumulative water deficit. For each annual average of environmental properties, grid points were grouped into 20 quantile bins: points represent the average within each bin, and shaded area corresponds to the $90 \%$ quantile range within each bin. Data source for annual means: surface downwelling shortwave irradiance data (CERES EBAF-Surface Ed4.0; Kato et al., 2013); precipitation (TMPA-3B43; Liu et al., 2012); maximum cumulative water deficit was based on the same approach as Malhi et al. (2009a), using the TMPA-3B43 precipitation.

higher contribution of individuals with DBH $>50 \mathrm{~cm}$ to basal area (Fig. 10a,b). Model comparison with TNF data also showed that the model reproduced the main characteristics of the forest structure, although the slope of abundance as a function of size was steeper in the model compared to observations (Fig. 10c). Basal area structure, on the other hand, showed good agreement with field inventory data and total basal area was within $5 \%$ of the observed basal area. 
Geosci. Model Dev. Discuss., https://doi.org/10.5194/gmd-2019-71

Manuscript under review for journal Geosci. Model Dev.

Discussion started: 28 March 2019

(c) Author(s) 2019. CC BY 4.0 License.

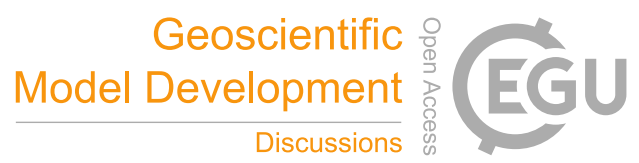

(c) (i)
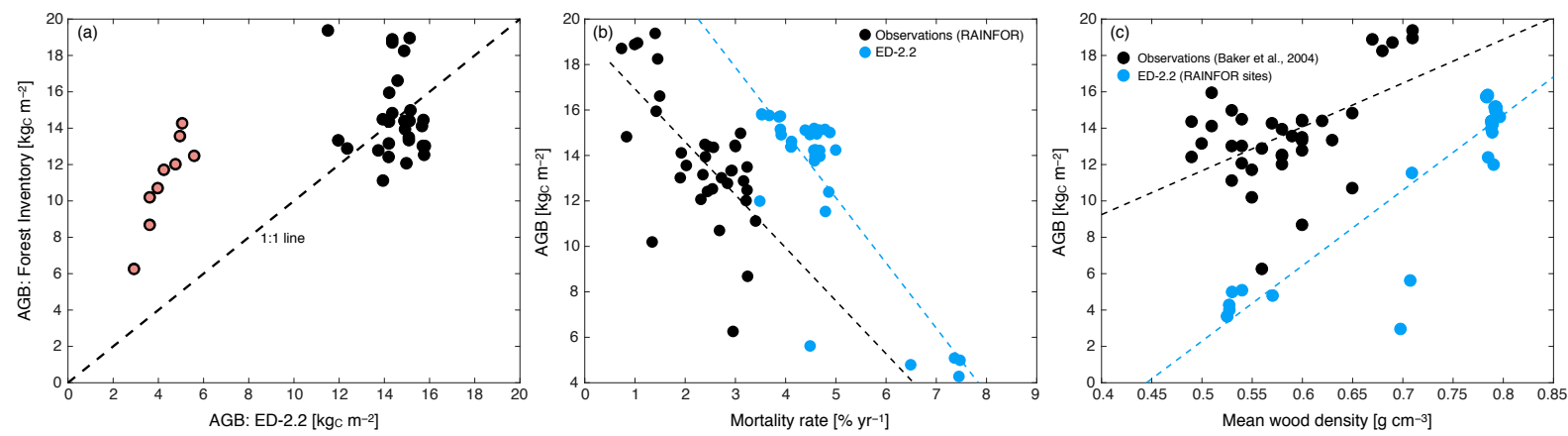

Figure 9. Evaluation of the ED-2.2 biomass and relationship between biomass and ecosystem function. (a) (Redrawn from Knox et al., 2015) Comparison of model estimated mean aboveground biomass (AGB) with field estimates at multiple sites presented in Baker et al. (2004a, b). To be consistent with field measurements, model estimates included only biomass from living individuals with $\mathrm{DBH} \geq 10 \mathrm{~cm}$ (diameter at breast height). Points in red are from drier forest sites in Bolivia. (b,c) (Redrawn from Levine et al., 2016). Steady-state aboveground biomass distribution across the Amazon as a function of (b) mortality rates and (c) basal-area weighted mean wood density, for both the ED-2.2 model (blue circles) and based on field observations (black circles). Source of field-based estimates: Phillips et al. (2004); Baker et al. (2004a, b).

Total mortality rates were generally higher in ED-2.2 simulations than based on the observed rates at both GYF and TNF (Fig. 11a,b), the model shows little variability in mortality between different census intervals. Most of the modeled mortality was due to background mortality, which is a combination of density-independent factors such as aging and treefall mortality, both assumed time-invariant in the model (Moorcroft et al., 2001). While the mortality due to environmental constrains (density-dependent) showed interannual variability, its magnitude was small, never exceeding $0.5 \% \mathrm{AGB}^{\mathrm{yr}^{-1}}$. The high mortality rates in the model is mostly attributable to early-successional trees, for which the modeled mortality rates was near

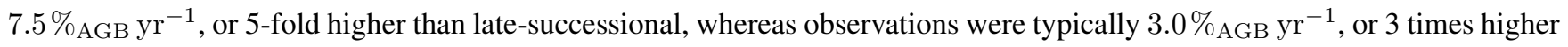
than late-successional. Likewise, growth rates were also higher than in observations, particularly at GYF (Fig. 11c), whereas the values were closer to observations for most of the simulated period at TNF (Fig. 11d). Growth rates of both sites are significantly different, which could be related to the particularly nutrient-poor soils at GYF (e.g, Baraloto et al., 2005), and that the ED-2.2 does not account for nutrient limitation. Alternatively, higher growth rates may be due to tree allometry and low allocation to living tissues and contributing to high accumulation rates on structural tissues.

\section{Discussion}

\subsection{Water and energy fluxes}

The comparisons with eddy covariance towers demonstrated the ability of ED-2.2 to simulate the magnitude and seasonality of both the evapotranspiration fluxes and the water storage in the canopy air space (Fig. 4;S1). The good agreement of evapotranspiration in the tropical sites using ED-2.2 contrasts with previous assessments using ED-2.1 for temperate sites, which found significant negative biases in simulated evapotranspiration and attributed the bias to the model overestimating the im- 
Geosci. Model Dev. Discuss., https://doi.org/10.5194/gmd-2019-71

Manuscript under review for journal Geosci. Model Dev.

Discussion started: 28 March 2019

(c) Author(s) 2019. CC BY 4.0 License.

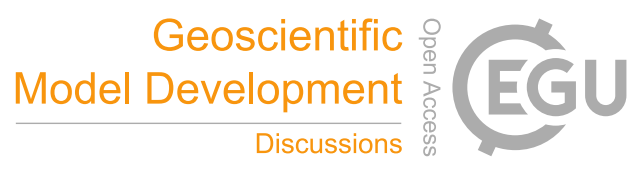

(c) (i)
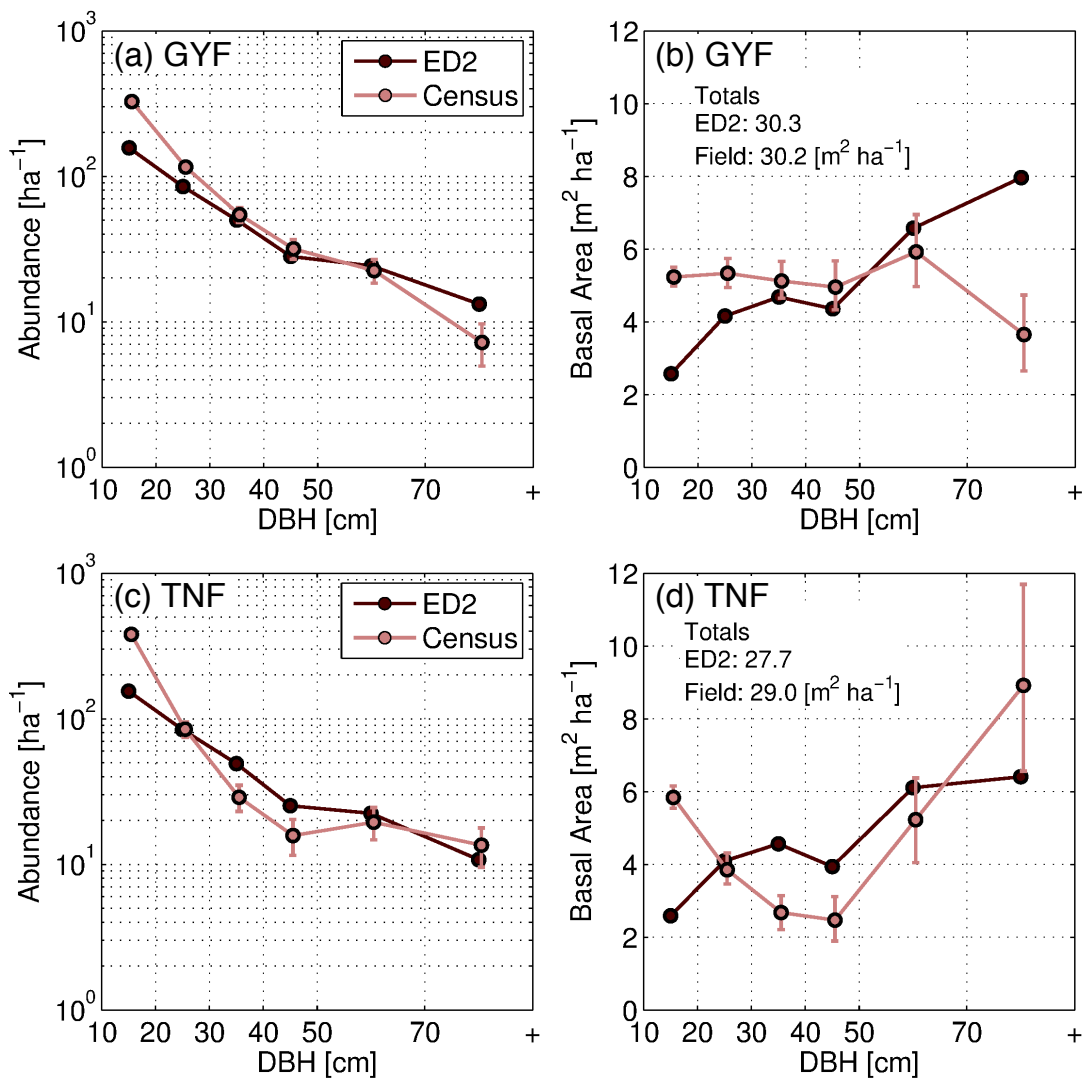

Figure 10. Evaluation of the ED-2.2 estimated size structure at the (a,b) GYF and (c,d) TNF sites, expressed in terms of abundance (a,c) and in terms of basal area (b,d). Confidence intervals on inventory analysis at $95 \%$ are shown with error bars. This is the confidence of the inventory sample representing the broader population (representativeness), as measurement error is assumed to be small. The confidence interval on abundance is estimated by a Poisson counting process. The confidence on the basal area is estimated by generating an ensemble of 100 random samples of the inventory, and quantile regression of the basal area sums of those re-samples. Total basal area predicted by ED-2.2 and observed in the census are shown in panels $(b, d)$.

pacts of water stress on stomatal conductance (Matheny et al., 2014; Walker et al., 2014). The average ratio between canopy evaporation and total rainfall ranged from $7-11 \%$ at the two forest sites tested here (Guyaflux and Tapajos), which is at the low end but in the same range of values founds in previous studies (9-20\%; Tobón Marin et al., 2000, and references therein). The hydrological cycle, on the other hand, showed some important deviations in absolute value, particularly near the surface, despite being consistent with observation in relative terms (Fig. S6). Large biases in absolute soil moisture were caused by the mismatches in the soil hydraulic properties that ultimately define the residual moisture and wilting point, field capacity, and porosity, thence the range of possible values of soil moisture. Soil hydraulic properties were derived from texture characteristics previously published for all sites. In ED-2.2 these properties were simplified to a single fraction assumed constant at every patch and throughout the profile, whereas in reality soil properties are known to vary significantly within the same area and 
Geosci. Model Dev. Discuss., https://doi.org/10.5194/gmd-2019-71

Manuscript under review for journal Geosci. Model Dev.

Discussion started: 28 March 2019

(c) Author(s) 2019. CC BY 4.0 License.

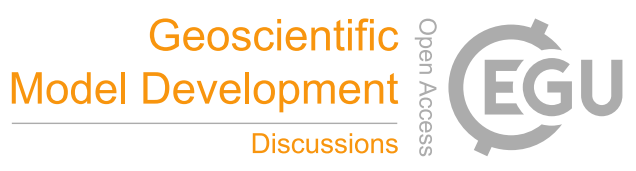

(c) (i)
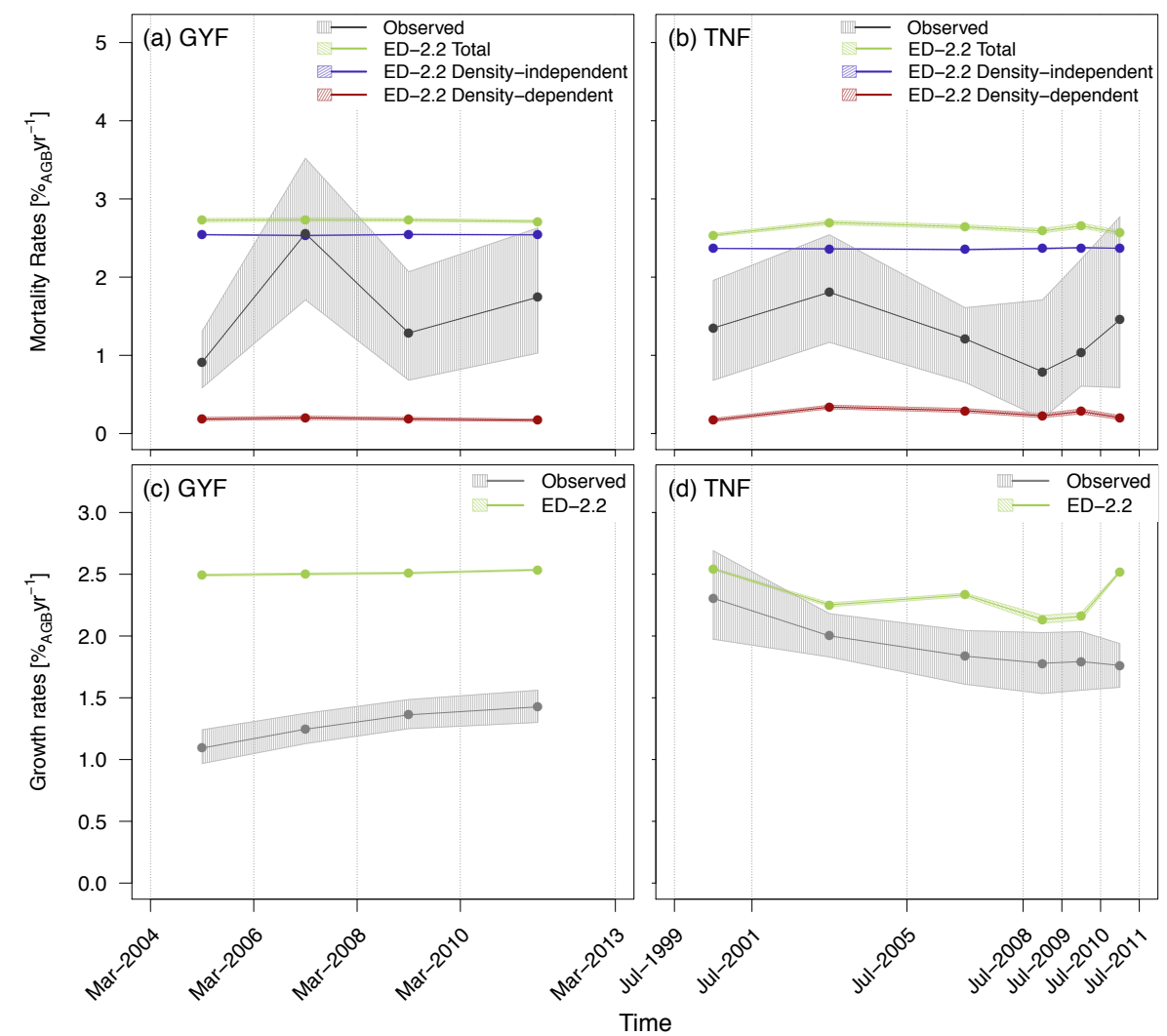

Figure 11. Comparison of $(a, b)$ mortality rates and (c,d) growth rates obtained from simulations and forest inventories for the (a,c) GYF and $(b, d)$ TNF sites. Vertical lines are the approximate times of forest inventory surveys, and bands associated with observations correspond to the $95 \%$ confidence interval, obtained from bootstrap (see Longo, 2014, for further details), and bands associated with model results are the range of simulations with different soil texture, leaf phenology, and initial time. To be consistent with the field plot protocol, only those cohorts with $\mathrm{DBH} \geq 10 \mathrm{~cm}$ (diameter at breast height) were included in the model estimates.

with depth (e.g. Epron et al., 2006). Moreover, soils in ED-2.2 are assumed to be mineral, whereas in reality macropores and soil organic content can substantially affect such properties (Saxton and Rawls, 2006; Fisher et al., 2008).

The model also realistically represented both the net absorption of visible irradiance and the vertical distribution throughout the canopy. The model showed similar magnitude and seasonality of the outgoing shortwave radiation, including photosynthetically active radiation, at the two long-term sites (Fig. 1), and the average light level profiles within the canopy. Agreement was even higher during cloudy conditions (Fig. 2), when the spatial distribution of individual trees has less of an impact on local variability in the light profile (Mercado et al., 2009). Differences were more significant for photosynthetically active radiation than for total shortwave radiation, particularly during the dry season (Fig. 1c,d). These differences may result from two factors. First, leaf optical properties in ED-2.2 are assumed constant for any given PFT, whereas observations indicate that leaf reflectivity depends on leaf age (Toomey et al., 2009; Chavana-Bryant et al., 2017). Second, ED-2.2 represents canopy structure in 
Geosci. Model Dev. Discuss., https://doi.org/10.5194/gmd-2019-71

Manuscript under review for journal Geosci. Model Dev.

Discussion started: 28 March 2019

(c) Author(s) 2019. CC BY 4.0 License.

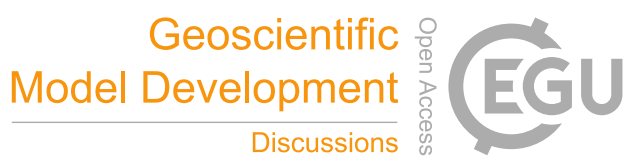

only one dimension for each patch, the effect of neighboring trees (or their absence) is not represented. A full three-dimensional approach similar to Morton et al. (2016) may not be feasible within the ED-2.2 because of the intensive computational burden and that the model does not represent the actual position of individual trees. Alternatively, the perfect plasticity approach (Purves et al., 2008; Farrior et al., 2013), in which finite-crown individual trees are arranged to maximize light access, has been

5 recently adapted to another cohort-based model, the Functionally-Assembled Terrestrial Ecosystem Simulator (FATES, Fisher et al., 2018). The perfect plasticity approach has the advantage of allowing trees of similar size to experience the same light levels (as opposed to the sequential light interception in ED-2.2), which could contribute to improve the light extinction profile in closed canopy forests. Importantly, while the current representation of vertical light distribution in ED-2.2 may affect light availability of individual cohorts, it does not imply that the simulated understory in ED-2.2 is excessively dark. In fact, when we compared the modeled and observed vertical structure of diffuse light (which is less sensitive to the observed position of trees than direct light) we found that the model slightly overestimates understory light levels (Fig. 2).

The model predictions of canopy air space temperature at TNF generally matches observations well, except for a slight overestimation during the dry season at TNF (Fig. S1). However, the sensible heat flux also tends to be higher than tower estimates, particularly at the drier TNF site (Fig. 3). The better agreement of simulated water fluxes with observations relative to sensible heat flux is very common among land surface models (Best et al., 2015). One possible cause of this disagreement is that observations from eddy flux towers typically contain significant sources and sinks from lateral advection and air drainage that may result in departures from energy closure by as much as 30\% (Tóta et al., 2008; da Rocha et al., 2009; Leuning et al., 2012; Stoy et al., 2013). Energy conservation is a requirement in ED-2.2 and conservation of energy is consistently checked every model time step (Longo et al., 2019). However, ED-2.2 does not represent lateral advection or air drainage, and may compensate such losses through an increase in eddy fluxes. Moreover, Haughton et al. (2016) suggested that parameterization problems, and not energy conservation, are the most likely cause for biases in land surface models. In ED-2.2, one possible issue is that the heat capacity of branches and leaves could be biased, allowing greater variability of temperature and higher sensible heat fluxes at the expense of reduced storage. To our knowledge, no long-term measurements of leaf or branch temperature exist for the Amazon sites, but differences in outgoing thermal-infrared irradiance (Fig. S2) suggest that the observed vegetation temperature during the afternoon may be lower and less variable than the model predictions. Additional measurements of leaf and wood heat capacity for tropical forests could improve the accuracy of leaf and branch temperatures in the model.

\subsection{Carbon fluxes and carbon storage}

Comparisons of GPP between the ED-2.2 model and tower-based estimates show that the model captures both the magnitude of GPP and the typical GPP response to light (Fig. 5). In ED-2.2, the seasonality at tropical forest sites is mostly driven by light, thus the maximum productivity often occurs during the dry season (Fig. 5a,b). Estimates of GPP based on eddy covariance towers, however, suggest a more complex pattern, with minimum occurring either during the wet season (GYF) or the transition from wet to dry season (TNF), and modestly increasing productivity during the dry season (Fig. 5a,b; see also Bonal et al., 2008; Restrepo-Coupe et al., 2013, 2017). GPP depends on multiple processes, and thus differences between ED-2.2 and tower estimates may be due to several factors including biases in the seasonality of leaf area and photosynthetic 
Geosci. Model Dev. Discuss., https://doi.org/10.5194/gmd-2019-71

Manuscript under review for journal Geosci. Model Dev.

Discussion started: 28 March 2019

(c) Author(s) 2019. CC BY 4.0 License.

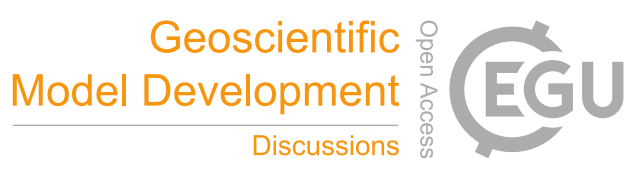

properties of leaves. In particular, empirical studies have shown that the seasonality of GPP in Amazon forests is linked to seasonal variation of photosynthetic capacity and leaf phenology (Wu et al., 2016; Restrepo-Coupe et al., 2017), whereas in the current implementation of ED-2.2 both the leaf turnover rate and the maximum photosynthetic capacity are assumed, for simplicity, to be constant. Work from several modeling studies (Kim et al., 2012; De Weirdt et al., 2012; Medvigy et al., 2013), and a leaf-level carbon optimization model (Xu et al., 2017) have shown that incorporating such seasonality into the dynamics of leaf longevity and photosynthetic capacity significantly improves predictions of the seasonality of carbon fluxes in tropical forests. However, data from multiple sites may be needed to develop a generalizable phenology model for evergreen forests.

The model estimates of ecosystem respiration were generally higher and more seasonal than the expected values either from eddy covariance tower estimates or from a bottom-up assessment, especially at GYF (Fig. 6; Table 1). In the model, the seasonality of ecosystem respiration was nearly exclusively driven by the seasonality in heterotrophic respiration, with a significant decline in the dry season due to lower soil moisture (Fig. 6c,d), whereas eddy covariance tower estimates suggest a dry-season reduction in respiration only at TNF (Fig. 6a,b; Restrepo-Coupe et al., 2017; Aguilos et al., 2018). The ED-2.2 assumption that heterotrophic respiration at lower soil moisture (Longo et al., 2019) is consistent with observations for total respiration at GYF (e.g. Fig. 3 of Aguilos et al., 2018); however, the magnitude of the heterotrophic response to moisture is likely overestimated in the ED-2.2 model.

Total autotrophic respiration estimates from ED-2.2 were within range with independent bottom-up estimates for both sites , albeit only marginally within the $95 \%$-confidence level ( 2 standard errors) of the bottom-up estimates at TNF (Table 1). At both sites, the simulated autotrophic respiration was driven by leaf and stem respiration, which contributed with roughly the same proportion to autotrophic respiration. In contrast, the bottom-up estimates at both sites suggest leaf respiration was 2-3 fold higher than stem respiration (Table 1). One possibility is that the allocation of carbon gains to tissue growth was overestimated in ED-2, which is consistent with the overestimated growth rates compared to forest inventory plots (Fig. 11). It must be noted, however, that several terms estimated from observations also carry large uncertainties and assumptions. For example, stem respiration is typically measured near the surface (e.g Chambers et al., 2004; Stahl, 2010), which may introduce biases given that branches may have significantly higher respiration rates (Cavaleri et al., 2006). Furthermore, observed differences of expected values between sites are generally much larger than the differences obtained by the model, and such differences may reflect true differences of plant community functioning between sites, or differences in sampling and techniques (Malhi et al., 2009b). Improved measurements of the different terms of ecosystem respiration would allow for improved constrains on the individual processes driving the total respiration.

In addition to tropical sites, the model's ability to represent productivity and respiration has been previously assessed for temperate ecosystems. The model showed excellent agreement in magnitude and seasonality of both net ecosystem productivity (NEP) and gross primary productivity (GPP) at three flux tower sites installed at Harvard Forest, in particular when the model was initialized with ground-based or remote-sensing-based data (Antonarakis et al., 2014). In contrast, the model showed significant biases in net primary productive under ambient $\mathrm{CO}_{2}$ at two Free-air $\mathrm{CO}_{2}$ Enrichment (FACE) sites in Southeastern United States, overestimating NPP at Duke (evergreen forest) and underestimating at Oak Ridge (deciduous forest) (Walker et al., 2014). Also, a previous model-intercomparison study for eleven North American tower sites also revealed significant 
Geosci. Model Dev. Discuss., https://doi.org/10.5194/gmd-2019-71

Manuscript under review for journal Geosci. Model Dev.

Discussion started: 28 March 2019

(c) Author(s) 2019. CC BY 4.0 License.

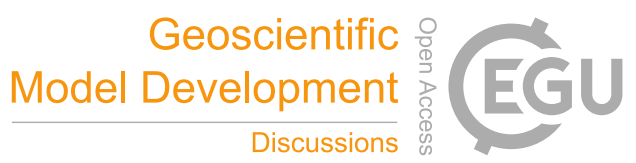

negative biases in ED-2.1, although the model inter-annual variability of GPP and ecosystem respiration were within the observed range for both deciduous and evergreen sites (Keenan et al., 2012). In addition, a wavelet analysis of the normalized error across 9 tower sites across North America suggested that the errors in net ecosystem exchange (NEE) are dominated by sub-annual (but longer than daily) time scales (Dietze et al., 2011). Together, these results indicate the need of quantifying which processes and parameters contribute the most to model uncertainties in order to improve the model predictions using ED-2.2, which is currently being pursued (Fer et al., 2018; Raczka et al., 2018).

Finally, because ED-2.2 solves the carbon dioxide cycles at sub-hourly scale, it also accounts for changes in storage in the canopy air space. As described in the companion paper (Longo et al., 2019), in ED-2.2, canopy air space storage is accounted for energy, water, and carbon dioxide. While changes in storage are generally small in the seasonal or multi-annual scale

(Fig. S5a,b), they may are not negligible in the sub-daily scale. The relevance of the storage of $\mathrm{CO}_{2}$ in the canopy air space has been long recognized by the eddy covariance community (e.g. Goulden et al., 1996; Bonal et al., 2008; Hayek et al., 2018), but only rarely included in biosphere or land surface models. For example, the strong release of carbon dioxide in the early morning hours, resulting from the nighttime accumulation of respired $\mathrm{CO}_{2}$, is well characterized by the model at both test sites (Fig. S5c,d). Accounting for this time lag between biologically-driven emission or uptake and the emissions to the free atmosphere is particularly important for benchmarking the model with the upcoming column-integrated measurements of $\mathrm{CO}_{2}$ Orbiting Carbon Observatory-3, which will provide samples at multiple times of the day (Eldering et al., 2017; Stavros et al., 2017).

\subsection{Long-term, large-scale ecosystem dynamics}

A key feature of the ED-2.2 model is the emergence of long-term, large-scale ecosystem composition, structure and function from spatially-localized, height-structured competition between individuals within the plant canopy. As seen in Fig. 8, the model's large-scale predictions are consistent with remote-sensing estimates of how AGB variability along key climatological gradients of incoming solar irradiance, rainfall, and dry-season severity. In addition, the regional pattern of AGB predicted by ED-2.2 reproduces several notable features present in the remotely-sensed based estimates of AGB (Fig. 7). In particular, the model captures the spatial extent of the Amazon forest, and reproduces two characteristic patterns of spatial variability in forest biomass, namely (i) the high biomass forests found in the Guiana Shield (near GYF) and in the area south of the TNF flux tower, and (ii) the area of lower biomass forest that runs east-to-west spanning the TNF and MDK sites.

The model's predictions of regional AGB also reveal important discrepancies. First, the model estimates are generally lower than the remote-sensing estimates of AGB in the drier savannas and xeric shrublands of central and Northeastern Brazil (Fig. 78). The low biomass estimates in drier regions is likely related to the simplified fire model used in the regional simulations. Following Moorcroft et al. (2001), fire occurrence within each climatological grid cell is controlled by a simple fixed soil moisture threshold, the area burned per year increases linearly as a function of the mean AGB within each grid cell, and no plants survive burn events. In reality, as previous work has shown (e.g. Cardoso et al., 2003; Cochrane, 2003; Andela et al., 2016), fire frequency, burn area, and fire severity are also strongly influenced by environmental factors in addition to soil moisture, such as proximity to roads and deforested areas. Moreover, the model does not account for size-related differences 
Geosci. Model Dev. Discuss., https://doi.org/10.5194/gmd-2019-71

Manuscript under review for journal Geosci. Model Dev.

Discussion started: 28 March 2019

(c) Author(s) 2019. CC BY 4.0 License.

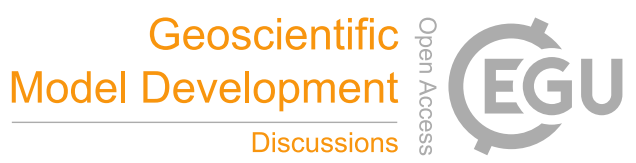

in fire survivorship and plant-functional diversity-related differences in fire survivorship arising from variation in plant traits such as bark-thickness-and re-sprouting ability (Brando et al., 2012; Trugman et al., 2018). Furthermore, the model simulations do not include plant functional types with adaptations for the semi-arid conditions typically observed in Northeastern Brazil. Such adaptations include smaller leaf size; internal water storage; modular, independent and redundant vascular systems; germination synchronized with rainfall; and Crassulacean Acid Metabolism (CAM) photosynthetic pathway (Cushman, 2001; Schenk et al., 2008; De Micco and Aronne, 2012). Incorporating these mechanisms that drive the ecosystem dynamics in drier areas could significant improve the model predictions outside tropical forests.

In the western Amazon, the model's predictions of AGB are generally higher than all three remote-sensing estimates, implying that the model is over-predicting AGB in this region (Fig. 7). ED-2.2 also tends to overestimate the high-biomass peak of the regional distribution of biomass (Fig. 8a). One potential reason for the AGB over-estimation in the Western Amazon is the model's predicted dominance of late-successional plants over most of the Amazon region, whereas field observations indicate that forests in Western Amazon have higher stem turnover rates and lower wood densities than Eastern Amazon (Phillips et al., 2004; ter Steege et al., 2006). This has been linked to the fact that soils in Western Amazon have higher nutrient availability (Quesada et al., 2012), which was not accounted for in ED-2.2. Finally, the regional simulation did not account for all types of anthropogenic disturbances from tropical forest degradation, which could also explain part of the overestimation by ED-2.2 compared to the remote-sensing estimates. Tropical forest degradation through selective logging, mining and low-intensity understory fires in the Amazon is pervasive along the arc of deforestation (e.g. Morton et al., 2013; Asner et al., 2013; Tyukavina et al., 2017) and is known to significantly deplete aboveground biomass (Berenguer et al., 2014; Longo et al., 2016; Rappaport et al., 2018).

The regional model simulation also qualitatively captures two disturbance-mediated relationships between canopy AGB and other tropical forest attributes observed in plot measurements (Fig. 9): the negative correlation between AGB and average stem mortality rates (Phillips et al., 2004; Johnson et al., 2016), and the positive correlation between AGB and average wood density found by Baker et al. (2004b). The fact that the model qualitatively captures the directional trend of both these two relationships is encouraging and suggests that the model's predictions of regional biomass trends are arising from mechanisms similar to those observed in nature. However, the magnitudes of the predicted relationships differ from the observations: for a given value of AGB, the model predicts a higher mean stem mortality rate and a higher mean wood density value than is observed in the plot measurements. The reasons for the differences in the magntidues of these relationships are, at present, unclear. However, in the case of the mean mortality-AGB relationship, the mismatch is likely related to the over-prediction of mortality rates seen in ED-2.2 (Fig. 9).

In this manuscript, we focused on assessing the model's ability to represent the dynamics of tropical forests, but previous studies have also shown that the model reasonably describes the dynamics of temperate ecosystems. For example, Medvigy and Moorcroft (2012) demonstrated that the model captures regional variation in both growth and mortality rates across forests of northeastern North America, especially when using the optimized parameters from Medvigy et al. (2009). Also, Miller et al. (2016) applied ED-2.1 at Duke's Free Air Carbon dioxide Enrichment experiment site (conifer-dominated) and found that the model accurately predicts biomass changes over time for both ambient and elevated $\mathrm{CO}_{2}$, and realistically characterizes the 
Geosci. Model Dev. Discuss., https://doi.org/10.5194/gmd-2019-71

Manuscript under review for journal Geosci. Model Dev.

Discussion started: 28 March 2019

(c) Author(s) 2019. CC BY 4.0 License.

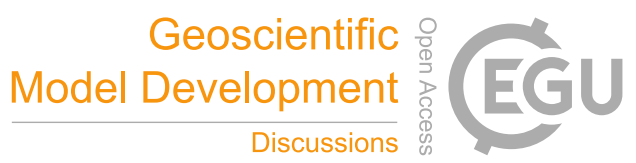

(c) (i)

changes in gross and net primary productivity (NPP) as functions of stand age. This result was consistent with a previous model-intercomparison study, which found good agreement on observed and ED-2.1 modeled $\mathrm{CO}_{2}$ fertilization effect at Duke, whereas the model predicted response to elevated $\mathrm{CO}_{2}$ at Oak Ridge (broadleaf-dominated) was overestimated (De Kauwe et al., 2013). In contrast, in a millennium-long model inter-comparison study for Northeastern United States, the model overestimated both the magnitude of NPP and its variability as a function of rainfall and $\mathrm{CO}_{2}$ when compared to tree-ring estimates (Rollinson et al., 2017), which indicates the need of constraining the model response for environmental conditions outside the current range.

\section{Conclusions}

Results from both observations and experimental studies have shown that plant diversity is an important determinant of terrestrial ecosystem function and how terrestrial eco fsystems respond to environmental perturbation (Tilman, 1996; Gunderson, 2000; Cadotte et al., 2011; Mori et al., 2013; Hautier et al., 2015; Falster et al., 2017). Terrestrial ecosystem models have advanced significantly towards representing functional diversity over large regions over the past twenty years (Moorcroft et al., 2001; Medvigy and Moorcroft, 2012; Fisher et al., 2015, 2018), however their ability to represent complex, heterogeneous communities also depends on their ability to represent the heterogeneity of the environments where plants live and compete for resources. The ED-2.2 model accounts for this fine-scale heterogeneity by solving the energy, water, and carbon cycles for the different micro-environments in the plant community. The ED-2.2 model integrates biosphysical, ecological and biogeochemical terrestrial ecosystem processes of heterogeneous landscapes on timescales ranging from minutes to centuries and on spatial scales ranging from individual plants to continental scales. As we have shown in the companion paper (Longo et al., 2019), the model shows excellent conservation of energy, water, and carbon dioxide that is a necessary condition for the model application to longer time scales and for accurate coupling with atmospheric models.

The thorough evaluation of the model, including an assessment of the separate components of the energy, water, and carbon cycles demonstrated the model's ability to represent multiple biophysical and biogeochemical mechanisms. The model dynamics are consistent with observations in most short-term fluxes of shortwave radiation (Fig. 1-2) and water (Fig. 4;S1), and even though it showed significant overestimation in sensible heat flux, the model characterized the average and the seasonality of canopy air space temperature (S1). The model represented realistic magnitude and light response curve of gross primary productivity (GPP), albeit it did not capture the GPP seasonality at TNF (Fig. 5). Respiration showed the highest disagreement, both in terms of magnitude and seasonality, reflecting the uncertainties in representing respiration processes (Fig. 6; Table 1). In addition to the short-term comparisons with eddy covariance towers, ED-2.2 also showed good agreement with independent estimates of aboveground biomass distribution at regional level in the tropics (Figs. 7-9) and the size distribution of the aggregated properties (Fig. 10), and reasonable magnitude of mortality rates and growth rates for TNF, an inland tropical forest site, although it significantly overestimated growth rates at GYF, a particularly nutrient-poor site (Fig. 11).

As pointed out in the companion model description manuscript (Longo et al., 2019), the ED-2.2 model continues to be developed. The ED-2.2 model evaluation presented here highlighted some short- and long-term processes that should be regarded 
Geosci. Model Dev. Discuss., https://doi.org/10.5194/gmd-2019-71

Manuscript under review for journal Geosci. Model Dev.

Discussion started: 28 March 2019

(c) Author(s) 2019. CC BY 4.0 License.

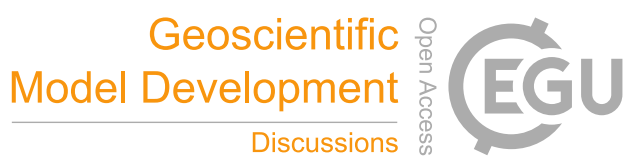

(c) (i)

as priorities for future developments. Better constrains in vegetation heat capacity could improve the quantification of energy storage and reduce biases in outgoing long wave radiation and sensible heat flux. Likewise, ecosystem respiration showed significant departures in magnitude and seasonality from site-level estimates. Formal optimization of parameters that control respiration response to temperature and moisture, along with better description of the range of decomposition time scales may

5 be required. Finally, the excessive tree growth rates identified in nutrient-poor sites could be addressed by expanding the representation of biogeochemical cycles in tropical forests by including nitrogen and phosphorus dynamics, which could significant improve the characterization of the carbon cycle.

Code and data availability. The ED-2.2 software and further developments are publicly available. The most up-to-date source code, postprocessing R scripts, and an open discussion forum are available on https://github.com/EDmodel/ED2. The code described in this manuscript, along with a wiki-based technical manual, is stored as a release at https://github.com/mpaiao/ED2/releases/tag/rev-85 and permanently stored at https://dx.doi.org/10.5281/zenodo.2579481. Eddy covariance data from GYF and TNF sites are available at https://fluxnet.fluxdata.org. Forest inventory are available upon request to the data PI: GYF - D.B. (damien.bonal@inra.fr); TNF - P.B.d.C (pcamargo@cena.usp.br). The PGMF meteorological data set can be requested at http://hydrology.princeton.edu/data.pgf.php. The Oak Ridge National Laboratory Distributed Active Archive Center provides access to the RADAMBRASIL (https://dx.doi.org/10.3334/ORNLDAAC/941), IGBP (http:// dx.doi.org/10.3334/ORNLDAAC/565) and the photosynthetically active radiation (https://dx.doi.org/10.3334/ORNLDAAC/899) data sets. Remote-sensing biomass maps were obtained by contacting the corresponding authors (Saatchi et al., 2011; Baccini et al., 2012), and from http://lucid.wur.nl (Avitabile et al., 2016). CERES EBAF-Surface and TMPA-3B43 products are available at https://ceres.larc.nasa.gov and https://dx.doi.org/10.5067/TRMM/TMPA/MONTH/7, respectively. MODIS Leaf area index product (MCD15A2H, Collection 6) is available at http://doi.org/10.5067/MODIS/MCD15A2H.006.

Author contributions. M.L., R.G.K., N.M.L., K.Z., R.L.B., S.C.W and P.R.M. designed the model assessment. M.L., R.G.K., N.M.L. and A.L.S.S. carried out the ED-2.2 simulations. D.B., B.B. P.B.C., M.N.H., S.C.S, R.d.S. and S.C.W contributed with observed meteorological, eddy flux, and forest inventory data. M.L., R.G.K., D.M.M., N.M.L., M.C.D., Y.K., A.L.S.S. and P.R.M wrote the paper.

Competing interests. The authors declare no competing interests.

Acknowledgements. The research was partially carried out at the Jet Propulsion Laboratory, California Institute of Technology, under a contract with the National Aeronautics and Space Administration. We thank Miriam Johnston and Luciana Alves for suggestions that improved the manuscript; Luciana Alves, Bruce Daube, David Fitzjarrald, Elaine Gottlieb, Elizabeth Pyle, Lucy Hutyra, Natalia Restrepo-Coupe, Raphael Tapajós, Scott Stark, and Kenia Wiedemann for the management and data processing; and Valerio Avitabile, Alessandro Baccini, and Sassan Saatchi for providing remote-sensing estimates of biomass. The model simulations were carried out at the Odyssey cluster, supported by the FAS Division of Science, Research Computing Group at Harvard University. M.L. was supported by Conselho Nacional de 
Geosci. Model Dev. Discuss., https://doi.org/10.5194/gmd-2019-71

Manuscript under review for journal Geosci. Model Dev.

Discussion started: 28 March 2019

(c) Author(s) 2019. CC BY 4.0 License.

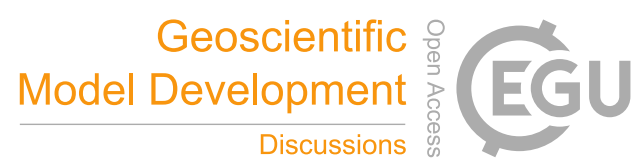

(c) (1)

Desenvolvimento Científico e Tecnológico (CNPq, grant 200686/2005-4), NASA Earth and Space Science Fellowship (NNX08AU95H) and National Science Foundation (NSF, grant OISE-0730305, Amazon-PIRE). R.G.K was supported by a National Science Foundation Grant ATM-0449793 and National Aeronautics and Space Administration Grant NNG06GD63G. A.L.S.S. was supported as a Giorgio Ruffolo

Fellow in the Sustainability Science Program at Harvard University, for which support from Italy's Ministry for Environment, Land and Sea 5 is gratefully acknowledged. 
Geosci. Model Dev. Discuss., https://doi.org/10.5194/gmd-2019-71

Manuscript under review for journal Geosci. Model Dev.

Discussion started: 28 March 2019

(c) Author(s) 2019. CC BY 4.0 License.

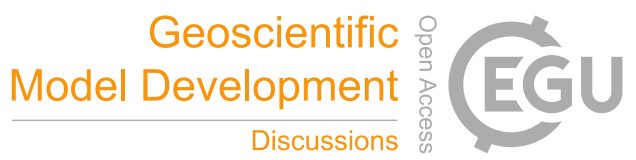

(c) (i)

\section{References}

Aguilos, M., Hérault, B., Burban, B., Wagner, F., and Bonal, D.: What drives long-term variations in carbon flux and balance in a tropical rainforest in French Guiana?, Agric. For. Meteorol., 253-254, 114-123, https://doi.org/10.1016/j.agrformet.2018.02.009, 2018.

Ahlström, A., Xia, J., Arneth, A., Luo, Y., and Smith, B.: Importance of vegetation dynamics for future terrestrial carbon cycling, Environ. Res. Lett., 10, 054 019, http://stacks.iop.org/1748-9326/10/i=5/a=054019, 2015.

Andela, N., van der Werf, G. R., Kaiser, J. W., van Leeuwen, T. T., Wooster, M. J., and Lehmann, C. E. R.: Biomass burning fuel consumption dynamics in the (sub)tropics assessed from satellite, Biogeosciences, 13, 3717-3734, https://doi.org/10.5194/bg-2015-582, 2016.

Antonarakis, A. S., Munger, J. W., and Moorcroft, P. R.: Imaging spectroscopy- and lidar-derived estimates of canopy composition and structure to improve predictions of forest carbon fluxes and ecosystem dynamics, Geophys. Res. Lett., 41, 2535-2542, https://doi.org/10.1002/2013GL058373, 2014.

Asner, G. P., Llactayo, W., Tupayachi, R., and Luna, E. R.: Elevated rates of gold mining in the Amazon revealed through high-resolution monitoring, Proc. Natl. Acad. Sci. U. S. A., 110, 18 454-18 459, https://doi.org/10.1073/pnas.1318271110, 2013.

Avitabile, V., Herold, M., Heuvelink, G. B. M., Lewis, S. L., Phillips, O. L., Asner, G. P., Armston, J., Ashton, P. S., Banin, L., Bayol, N., Berry, N. J., Boeckx, P., de Jong, B. H. J., DeVries, B., Girardin, C. A. J., Kearsley, E., Lindsell, J. A., Lopez-Gonzalez, G., Lucas, R., Malhi, Y., Morel, A., Mitchard, E. T. A., Nagy, L., Qie, L., Quinones, M. J., Ryan, C. M., Ferry, S. J. W., Sunderland, T., Laurin, G. V., Gatti, R. C., Valentini, R., Verbeeck, H., Wijaya, A., and Willcock, S.: An integrated pan-tropical biomass map using multiple reference datasets, Glob. Change Biol., 22, 1406-1420, https://doi.org/10.1111/gcb.13139, 2016.

Baccini, A., Goetz, S. J., Walker, W. S., Laporte, N. T., Sun, M., Sulla-Menashe, D., Hackler, J., Beck, P. S. A., Dubayah, R., Friedl, M. A., Samanta, S., and Houghton, R. A.: Estimated carbon dioxide emissions from tropical deforestation improved by carbon-density maps, Nature Clim. Change, 2, 182-185, https://doi.org/10.1038/nclimate1354, 2012.

Baker, T. R., Phillips, O. L., Malhi, Y., Almeida, S., Arroyo, L., Di Fiore, A., Erwin, T., Higuchi, N., Killeen, T. J., Laurance, S. G., Laurance, W. F., Lewis, S. L., Monteagudo, A., Neill, D. A., Núñez Vargas, P., Pitman, N. C. A., Silva, J. N. M., and Vásquez Martínez, R.: Increasing biomass in Amazonian forest plots, Philos. Trans. R. Soc. B-Biol. Sci., 359, 353-365, https://doi.org/10.1098/rstb.2003.1422, 2004a.

Baker, T. R., Phillips, O. L., Malhi, Y., Almeida, S., Arroyo, L., Di Fiore, A., Erwin, T., Killeen, T. J., Laurance, S. G., Laurance, W. F., Lewis, S. L., Lloyd, J., Monteagudo, A., Neill, D. A., Patiño, S., Pitman, N. C. A., M. Silva, J. N., and Vásquez Martínez, R.: Variation in wood density determines spatial patterns in Amazonian forest biomass, Glob. Change Biol., 10, 545-562, https://doi.org/10.1111/j.13652486.2004.00751.x, 2004b.

Baraloto, C., Goldberg, D. E., and Bonal, D.: Performance trade-offs among tropical tree seedlings in contrasting microhabitats, Ecology, 86, 2461-2472, https://doi.org/10.1890/04-1956, 2005.

30 Berenguer, E., Ferreira, J., Gardner, T. A., Aragão, L. E. O. C., de Camargo, P. B., Cerri, C. E., Durigan, M., Oliveira, R. C. D., Vieira, I. C. G. a., and Barlow, J.: A large-scale field assessment of carbon stocks in human-modified tropical forests, Glob. Change Biol., 20, 3713-3726, https://doi.org/10.1111/gcb.12627, 2014.

Best, M. J., Abramowitz, G., Johnson, H. R., Pitman, A. J., Balsamo, G., Boone, A., Cuntz, M., Decharme, B., Dirmeyer, P. A., Dong, J., Ek, M., Guo, Z., Haverd, V., van den Hurk, B. J. J., Nearing, G. S., Pak, B., Peters-Lidard, C., Santanello, J. A., Stevens, L., and Vuichard, N.: The Plumbing of Land Surface Models: Benchmarking Model Performance, J. Hydrometeor., 16, 1425-1442, https://doi.org/10.1175/JHM-D-14-0158.1, 2015. 
Geosci. Model Dev. Discuss., https://doi.org/10.5194/gmd-2019-71

Manuscript under review for journal Geosci. Model Dev.

Discussion started: 28 March 2019

(c) Author(s) 2019. CC BY 4.0 License.

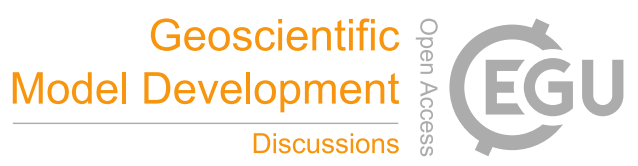

(c) (i)

Bonal, D., Bosc, A., Ponton, S., Goret, J.-Y., Burban, B., Gross, P., Bonnefond, J.-M., Elbers, J., Longdoz, B., Epron, D., Guehl, J.-M., and Granier, A.: Impact of severe dry season on net ecosystem exchange in the Neotropical rainforest of French Guiana, Glob. Change Biol., 14, 1917-1933, https://doi.org/10.1111/j.1365-2486.2008.01610.x, 2008.

Brando, P. M., Nepstad, D. C., Balch, J. K., Bolker, B., Christman, M. C., Coe, M., and Putz, F. E.: Fire-induced tree mortality in a neotropical forest: the roles of bark traits, tree size, wood density and fire behavior, Glob. Change Biol., 18, 630-641, https://doi.org/10.1111/j.13652486.2011.02533.x, 2012.

Cabral, O. M. R., McWilliam, A.-L. C., and Roberts, J. M.: In-canopy microclimate of Amazonian forest and estimates of transpiration, in: Amazon deforestation and climate, edited by Gash, J. H. C., Nobre, C. A., Roberts, J. M., and Victoria, R. L., chap. 12, pp. 207-219, John Wiley \& Sons, Inc., Chichester, West Sussex, United Kingdom, 1996.

Cadotte, M. W., Carscadden, K., and Mirotchnick, N.: Beyond species: functional diversity and the maintenance of ecological processes and services, J. Appl. Ecol., 48, 1079-1087, https://doi.org/10.1111/j.1365-2664.2011.02048.x, 2011.

Cardoso, M. F., Hurtt, G. C., Moore III, B., Nobre, C. A., and Prins, E. M.: Projecting future fire activity in Amazonia, Glob. Change Biol., 9, 656-669, https://doi.org/10.1046/j.1365-2486.2003.00607.x, 2003.

Cavaleri, M. A., Oberbauer, S. F., and Ryan, M. G.: Wood $\mathrm{CO}_{2}$ efflux in a primary tropical rain forest, Glob. Change Biol., 12, 2442-2458, https://doi.org/10.1111/j.1365-2486.2006.01269.x, 2006.

Chambers, J. Q., Tribuzy, E. S., Toledo, L. C., Crispim, B. F., Higuchi, N., Santos, J. d., Araújo, A. C., Kruijt, B., Nobre, A. D., and Trumbore, S. E.: Respiration from a tropical forest ecosystem: partitioning of sources and low carbon use efficiency, Ecol. Appl., 14, S72-S88, https://doi.org/10.1890/01-6012, 2004.

Chavana-Bryant, C., Malhi, Y., Wu, J., Asner, G. P., Anastasiou, A., Enquist, B. J., Cosio Caravasi, E. G., Doughty, C. E., Saleska, S. R., Martin, R. E., and Gerard, F. F.: Leaf aging of Amazonian canopy trees as revealed by spectral and physiochemical measurements, New Phytol., 214, 1049-1063, https://doi.org/10.1111/nph.13853, 2017.

Chave, J., Coomes, D., Jansen, S., Lewis, S. L., Swenson, N. G., and Zanne, A. E.: Towards a worldwide wood economics spectrum, Ecol. Lett., 12, 351-366, https://doi.org/10.1111/j.1461-0248.2009.01285.x, 2009.

Cochrane, M. A.: Fire science for rainforests, Nature, 421, 913-919, https://doi.org/10.1038/nature01437, 2003.

Cushman, J. C.: Crassulacean acid metabolism. A plastic photosynthetic adaptation to arid environments, Plant Physiol., 127, 1439-1448, https://doi.org/10.1104/pp.010818, 2001.

da Rocha, H. R., Manzi, A. O., and Shuttleworth, W. J.: Evapotranspiration, in: Amazonia and Global Change, edited by Keller, M., Bustamante, M., Gash, J., and Silva Dias, P. L., vol. 186 of Geophysical Monograph, chap. 16, pp. 261-272, American Geophysical Union, Washington, DC, USA, https://doi.org/10.1029/2008GM000817, 2009.

de Gonçalves, L. G. G., Restrepo-Coupe, N., da Rocha, H. R., Saleska, S. R., and Stockli, R.: LBA-ECO CD-32 LBA Model Intercomparison Project (LBA-MIP) Forcing Data, https://doi.org/10.3334/ORNLDAAC/1177, http://daac.ornl.gov, oak Ridge National Laboratory Distributed Active Archive Center, Oak Ridge, Tennessee, U.S.A., 2013.

De Kauwe, M. G., Medlyn, B. E., Zaehle, S., Walker, A. P., Dietze, M. C., Hickler, T., Jain, A. K., Luo, Y., Parton, W. J., Prentice, I. C., Smith, B., Thornton, P. E., Wang, S., Wang, Y.-P., Wårlind, D., Weng, E., Crous, K. Y., Ellsworth, D. S., Hanson, P. J., Seok Kim, H., Warren, J. M., Oren, R., and Norby, R. J.: Forest water use and water use efficiency at elevated $\mathrm{CO}_{2}$ : a model-data intercomparison at two contrasting temperate forest FACE sites, Glob. Change Biol., 19, 1759-1779, https://doi.org/10.1111/gcb.12164, 2013. 
Geosci. Model Dev. Discuss., https://doi.org/10.5194/gmd-2019-71

Manuscript under review for journal Geosci. Model Dev.

Discussion started: 28 March 2019

(c) Author(s) 2019. CC BY 4.0 License.

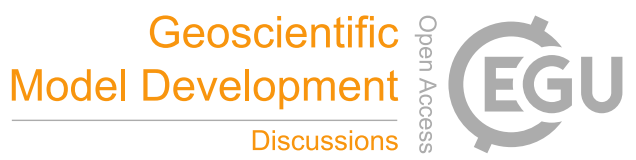

(c) (i)

De Micco, V. and Aronne, G.: Morpho-Anatomical Traits for Plant Adaptation to Drought, in: Plant responses to drought stress: from morphological to molecular features, edited by Aroca, R., chap. 2, pp. 37-61, Springer-Verlag Berlin Heidelberg, Heidelberg, Germany, https://doi.org/10.1007/978-3-642-32653-0_2, 2012.

de Negreiros, G. H., Alencar, A. C., Schlesinger, P., Nepstad, D. C., and Lefebvre, P. A.: Pre-LBA RADAMBRASIL project data., https://doi.org/10.3334/ORNLDAAC/941, http://daac.orln.gov, 2009.

De Weirdt, M., Verbeeck, H., Maignan, F., Peylin, P., Poulter, B., Bonal, D., Ciais, P., and Steppe, K.: Seasonal leaf dynamics for tropical evergreen forests in a process-based global ecosystem model, Geosci. Model Dev., 5, 1091-1108, https://doi.org/10.5194/gmd-5-1091$2012,2012$.

Dietze, M. C., Vargas, R., Richardson, A. D., Stoy, P. C., Barr, A. G., Anderson, R. S., Arain, M. A., Baker, I. T., Black, T. A., Chen, J. M.,

Ciais, P., Flanagan, L. B., Gough, C. M., Grant, R. F., Hollinger, D., Izaurralde, R. C., Kucharik, C. J., Lafleur, P., Liu, S., Lokupitiya, E., Luo, Y., Munger, J. W., Peng, C., Poulter, B., Price, D. T., Ricciuto, D. M., Riley, W. J., Sahoo, A. K., Schaefer, K., Suyker, A. E., Tian, H., Tonitto, C., Verbeeck, H., Verma, S. B., Wang, W., and Weng, E.: Characterizing the performance of ecosystem models across time scales: A spectral analysis of the North American Carbon Program site-level synthesis, J. Geophys. Res.-Biogeosci., 116, G04 029, https://doi.org/10.1029/2011JG001661, 2011.

Eldering, A., Wennberg, P. O., Crisp, D., Schimel, D. S., Gunson, M. R., Chatterjee, A., Liu, J., Schwandner, F. M., Sun, Y., O’Dell, C. W., Frankenberg, C., Taylor, T., Fisher, B., Osterman, G. B., Wunch, D., Hakkarainen, J., Tamminen, J., and Weir, B.: The Orbiting Carbon Observatory-2 early science investigations of regional carbon dioxide fluxes, Science, 358, eaam5745, https://doi.org/10.1126/science.aam5745, 2017.

Epron, D., Bosc, A., Bonal, D., and Freycon, V.: Spatial variation of soil respiration across a topographic gradient in a tropical rain forest in

French Guiana, J. Trop. Ecol., 22, 565-574, https://doi.org/10.1017/S0266467406003415, 2006.

Erb, K.-H., Kastner, T., Plutzar, C., Bais, A. L. S., Carvalhais, N., Fetzel, T., Gingrich, S., Haberl, H., Lauk, C., Niedertscheider, M., Pongratz,

J., Thurner, M., and Luyssaert, S.: Unexpectedly large impact of forest management and grazing on global vegetation biomass, Nature, 553, 73-76, https://doi.org/10.1038/nature25138, 2018.

Evans, M. R.: Modelling ecological systems in a changing world, Philos. Trans. R. Soc. B-Biol. Sci., 367, 181-190, https://doi.org/10.1098/rstb.2011.0172, 2012.

Falster, D. S., Brännström, Å., Westoby, M., and Dieckmann, U.: Multitrait successional forest dynamics enable diverse competitive coexistence, Proc. Natl. Acad. Sci. U. S. A., 114, E2719-E2728, https://doi.org/10.1073/pnas.1610206114, 2017.

Farrior, C. E., Dybzinski, R., Levin, S. A., and Pacala, S. W.: Competition for Water and Light in Closed-Canopy Forests: A Tractable Model of Carbon Allocation with Implications for Carbon Sinks., Am. Nat., 181, 314-330, https://doi.org/10.1086/669153, 2013.

Fer, I., Kelly, R., Moorcroft, P. R., Richardson, A. D., Cowdery, E. M., and Dietze, M. C.: Linking big models to big data: efficient ecosystem model calibration through Bayesian model emulation, Biogeosciences, 15, 5801-5830, https://doi.org/10.5194/bg-15-5801-2018, 2018.

Fisher, R. A., Williams, M., Ruivo, M. d. L., de Costa, A. L., and Meir, P.: Evaluating climatic and soil water controls on evapotranspiration at two Amazonian rainforest sites, Agric. For. Meteorol., 148, 850-861, https://doi.org/10.1016/j.agrformet.2007.12.001, 2008.

Fisher, R. A., Muszala, S., Vertenstein, M., Lawrence, P., Xu, C., McDowell, N. G., Knox, R. G., Koven, C., Holm, J., Rogers, B. M., Lawrence, D., and Bonan, G.: Taking off the training wheels: the properties of a dynamic vegetation model without climate envelopes, Geosci. Model Dev., 8, 3593-3619, https://doi.org/10.5194/gmd-8-3593-2015, 2015.

Fisher, R. A., Koven, C. D., Anderegg, W. R. L., Christoffersen, B. O., Dietze, M. C., Farrior, C., Holm, J. A., Hurtt, G., Knox, R. G., Lawrence, P. J., Lichststein, J. W., Longo, M., Matheny, A. M., Medvigy, D., Muller-Landau, H. C., Powell, T. L., Serbin, S. P., Sato, H., 
Geosci. Model Dev. Discuss., https://doi.org/10.5194/gmd-2019-71

Manuscript under review for journal Geosci. Model Dev.

Discussion started: 28 March 2019

(c) Author(s) 2019. CC BY 4.0 License.

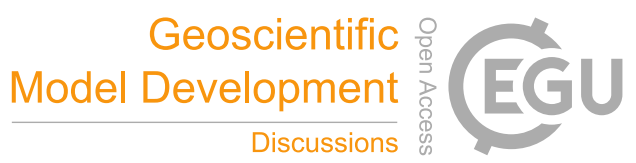

(c) ()

Shuman, J., Smith, B., Trugman, A. T., Viskari, T., Verbeeck, H., Weng, E., Xu, C., Xu, X., Zhang, T., and Moorcroft, P.: Vegetation Demographics in Earth System Models: a review of progress and priorities, Glob. Change Biol., 24, 35-54, https://doi.org/10.1111/gcb.13910, 2018.

Friedlingstein, P., Cox, P., Betts, R., Bopp, L., von Bloh, W., Brovkin, V., Cadule, P., Doney, S., Eby, M., Fung, I., Bala, G., John, J., Jones, C., Joos, F., Kato, T., Kawamiya, M., Knorr, W., Lindsay, K., Matthews, H. D., Raddatz, T., Rayner, P., Reick, C., Roeckner, E., Schnitzler, K. G., Schnur, R., Strassmann, K., Weaver, A. J., Yoshikawa, C., and Zeng, N.: Climate-Carbon Cycle Feedback Analysis: Results from the $C^{4}$ MIP Model Intercomparison, J. Climate, 19, 3337-3353, https://doi.org/10.1175/JCLI3800.1, 2006.

Friedlingstein, P., Meinshausen, M., Arora, V. K., Jones, C. D., Anav, A., Liddicoat, S. K., and Knutti, R.: Uncertainties in CMIP5 Climate Projections due to Carbon Cycle Feedbacks, J. Climate, 27, 511-526, https://doi.org/10.1175/JCLI-D-12-00579.1, 2014.

Goulden, M. L., Munger, J. W., Fan, S.-M., Daube, B. C., and Wofsy, S. C.: Measurements of carbon sequestration by long-term eddy covariance: methods and a critical evaluation of accuracy, Glob. Change Biol., 2, 169-182, https://doi.org/10.1111/j.1365-2486.1996.tb00070.x, 1996.

Gunderson, L. H.: Ecological Resilience - in theory and application, Annu. Rev. Ecol. Syst., 31, 425-439, https://doi.org/10.1146/annurev.ecolsys.31.1.425, 2000.

Haughton, N., Abramowitz, G., Pitman, A. J., Or, D., Best, M. J., Johnson, H. R., Balsamo, G., Boone, A., Cuntz, M., Decharme, B., Dirmeyer, P. A., Dong, J., Ek, M., Guo, Z., Haverd, V., van den Hurk, B. J. J., Nearing, G. S., Pak, B., Santanello, J. A., Stevens, L. E., and Vuichard, N.: The Plumbing of Land Surface Models: Is Poor Performance a Result of Methodology or Data Quality?, J. Hydrometeor., 17, 1705-1723, https://doi.org/10.1175/JHM-D-15-0171.1, 2016.

Hautier, Y., Tilman, D., Isbell, F., Seabloom, E. W., Borer, E. T., and Reich, P. B.: Anthropogenic environmental changes affect ecosystem stability via biodiversity, Science, 348, 336-340, https://doi.org/10.1126/science.aaa1788, 2015.

Hayek, M. N., Wehr, R., Longo, M., Hutyra, L. R., Wiedemann, K., Munger, J. W., Bonal, D., Saleska, S. R., Fitzjarrald, D. R., and Wofsy, S. C.: A novel correction for biases in forest eddy covariance carbon balance, Agric. For. Meteorol., 250-251, 90-101, https://doi.org/10.1016/j.agrformet.2017.12.186, 2018.

Hurtt, G. C., Frolking, S., Fearon, M. G., Moore, B., Shevliakova, E., Malyshev, S., Pacala, S. W., and Houghton, R. A.: The underpinnings of land-use history: three centuries of global gridded land-use transitions, wood-harvest activity, and resulting secondary lands., Glob. Change Biol., 12, 1208-1229, https://doi.org/10.1111/j.1365-2486.2006.01150.x, 2006.

Hutyra, L. R., Munger, J. W., Hammond-Pyle, E., Saleska, S. R., Restrepo-Coupe, N., Daube, B. C., de Camargo, P. B., and Wofsy, S. C.: Resolving systematic errors in estimates of net ecosystem exchange of $\mathrm{CO}_{2}$ and ecosystem respiration in a tropical forest biome, Agric. For. Meteorol., 148, 1266-1279, https://doi.org/10.1016/j.agrformet.2008.03.007, 2008.

Johnson, M. O., Galbraith, D., Gloor, M., De Deurwaerder, H., Guimberteau, M., Rammig, A., Thonicke, K., Verbeeck, H., von Randow, C., Monteagudo, A., Phillips, O. L., Brienen, R. J. W., Feldpausch, T. R., Lopez Gonzalez, G., Fauset, S., Quesada, C. A., Christoffersen, B., Ciais, P., Sampaio, G., Kruijt, B., Meir, P., Moorcroft, P., Zhang, K., Alvarez-Davila, E., Alves de Oliveira, A., Amaral, I., Andrade, A., Aragao, L. E. O. C., Araujo-Murakami, A., Arets, E. J. M. M., Arroyo, L., Aymard, G. A., Baraloto, C., Barroso, J., Bonal, D., Boot, R., Camargo, J., Chave, J., Cogollo, A., Cornejo Valverde, F., Lola da Costa, A. C., Di Fiore, A., Ferreira, L., Higuchi, N., Honorio, E. N., Killeen, T. J., Laurance, S. G., Laurance, W. F., Licona, J., Lovejoy, T., Malhi, Y., Marimon, B., Marimon, B. H., Matos, D. C. L., Mendoza, C., Neill, D. A., Pardo, G., Peña-Claros, M., Pitman, N. C. A., Poorter, L., Prieto, A., Ramirez-Angulo, H., Roopsind, A., Rudas, A., Salomao, R. P., Silveira, M., Stropp, J., ter Steege, H., Terborgh, J., Thomas, R., Toledo, M., Torres-Lezama, A., van der Heijden, G. M. F., Vasquez, R., Guimarães Vieira, I. C., Vilanova, E., Vos, V. A., and Baker, T. R.: Variation in stem mortality rates determines patterns 
Geosci. Model Dev. Discuss., https://doi.org/10.5194/gmd-2019-71

Manuscript under review for journal Geosci. Model Dev.

Discussion started: 28 March 2019

(c) Author(s) 2019. CC BY 4.0 License.

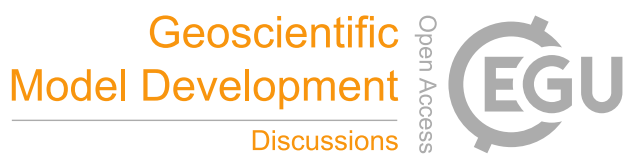

(c) (i)

of above-ground biomass in Amazonian forests: implications for dynamic global vegetation models, Glob. Change Biol., 22, 3996-4013, https://doi.org/10.1111/gcb.13315, 2016.

Kato, S., Loeb, N. G., Rose, F. G., Doelling, D. R., Rutan, D. A., Caldwell, T. E., Yu, L., and Weller, R. A.: Surface Irradiances Consistent with CERES-Derived Top-of-Atmosphere Shortwave and Longwave Irradiances, J. Climate, 26, 2719-2740, https://doi.org/10.1175/JCLID-12-00436.1, 2013.

Keenan, T., Baker, I., Barr, A., Ciais, P., Davis, K., Dietze, M., Dragoni, D., Gough, C. M., Grant, R., Hollinger, D., Hufkens, K., Poulter, B., McCaughey, H., Raczka, B., Ryu, Y., Schaefer, K., Tian, H., Verbeeck, H., Zhao, M., and Richardson, A. D.: Terrestrial biosphere model performance for inter-annual variability of land-atmosphere $\mathrm{CO}_{2}$ exchange, Glob. Change Biol., 18, 1971-1987, https://doi.org/10.1111/j.1365-2486.2012.02678.x, 2012

Kim, Y., Knox, R. G., Longo, M., Medvigy, D., Hutyra, L. R., Pyle, E. H., Wofsy, S. C., Bras, R. L., and Moorcroft, P. R.: Seasonal carbon dynamics and water fluxes in an Amazon rainforest, Glob. Change Biol., 18, 1322-1334, https://doi.org/10.1111/j.1365-2486.2011.02629.x, 2012.

Knox, R. G., Longo, M., Swann, A. L. S., Zhang, K., Levine, N. M., Moorcroft, P. R., and Bras, R. L.: Hydrometeorological effects of historical land-conversion in an ecosystem-atmosphere model of Northern South America, Hydrol. Earth Syst. Sci., 19, 241-273, https://doi.org/10.5194/hess-19-241-2015, 2015.

Kraft, N. J. B., Metz, M. R., Condit, R. S., and Chave, J.: The relationship between wood density and mortality in a global tropical forest data set, New Phytol., 188, 1124-1136, https://doi.org/10.1111/j.1469-8137.2010.03444.x, 2010.

Krause, A., Pugh, T. A. M., Bayer, A. D., Li, W., Leung, F., Bondeau, A., Doelman, J. C., Humpenöder, F., Anthoni, P., Bodirsky, B. L., Ciais, P., Müller, C., Murray-Tortarolo, G., Olin, S., Popp, A., Sitch, S., Stehfest, E., and Arneth, A.: Large uncertainty in carbon uptake potential of land-based climate-change mitigation efforts, Glob. Change Biol., 24, 3025-3038, https://doi.org/10.1111/gcb.14144, 2018.

Le Quéré, C., Andrew, R. M., Friedlingstein, P., Sitch, S., Hauck, J., Pongratz, J., Pickers, P. A., Korsbakken, J. I., Peters, G. P., Canadell, J. G., Arneth, A., Arora, V. K., Barbero, L., Bastos, A., Bopp, L., Chevallier, F., Chini, L. P., Ciais, P., Doney, S. C., Gkritzalis, T., Goll, D. S., Harris, I., Haverd, V., Hoffman, F. M., Hoppema, M., Houghton, R. A., Hurtt, G., Ilyina, T., Jain, A. K., Johannessen, T., Jones, C. D., Kato, E., Keeling, R. F., Goldewijk, K. K., Landschützer, P., Lefèvre, N., Lienert, S., Liu, Z., Lombardozzi, D., Metzl, N., Munro, D. R., Nabel, J. E. M. S., Nakaoka, S.-I., Neill, C., Olsen, A., Ono, T., Patra, P., Peregon, A., Peters, W., Peylin, P., Pfeil, B., Pierrot, D., Poulter, B., Rehder, G., Resplandy, L., Robertson, E., Rocher, M., Rödenbeck, C., Schuster, U., Schwinger, J., Séférian, R., Skjelvan, I., Steinhoff, T., Sutton, A., Tans, P. P., Tian, H., Tilbrook, B., Tubiello, F. N., van der Laan Luijkx, I. T., van der Werf, G. R., Viovy, N., Walker, A. P., Wiltshire, A. J., Wright, R., Zaehle, S., and Zheng, B.: Global Carbon Budget 2018, Earth System Science Data, 10, 2141-2194, https://doi.org/10.5194/essd-10-2141-2018, 2018.

Leuning, R., van Gorsel, E., Massman, W. J., and Isaac, P. R.: Reflections on the surface energy imbalance problem, Agric. For. Meteorol., 156, 65-74, https://doi.org/10.1016/j.agrformet.2011.12.002, 2012.

Levine, N. M., Zhang, K., Longo, M., Baccini, A., Phillips, O. L., Lewis, S. L., Alvarez, E., de Andrade, A. C. S., Brienen, R., Erwin, T., Feldpausch, T. R., Mendoza, A. L. M., Vargas, P. N., Prieto, A., Espejo, J. E. S., Malhi, Y., and Moorcroft, P. R.: Ecosystem heterogeneity determines the resilience of the Amazon to Climate Change, Proc. Natl. Acad. Sci. U. S. A., 113, 793-797, https://doi.org/10.1073/pnas.1511344112, 2016.

Liu, Z., Ostrenga, D., Teng, W., and Kempler, S.: Tropical Rainfall Measuring Mission (TRMM) Precipitation Data and Services for Research and Applications, Bull. Am. Meteorol. Soc., 93, 1317-1325, https://doi.org/10.1175/BAMS-D-11-00152.1, 2012. 
Geosci. Model Dev. Discuss., https://doi.org/10.5194/gmd-2019-71

Manuscript under review for journal Geosci. Model Dev.

Discussion started: 28 March 2019

(c) Author(s) 2019. CC BY 4.0 License.

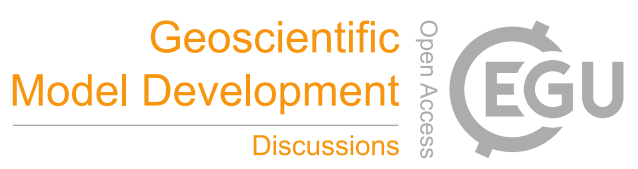

(c) (i)

Longo, M.: Amazon forest response to changes in rainfall regime: results from an individual-based dynamic vegetation model, Ph.D. dissertation, Harvard University, Cambridge, MA, http://nrs.harvard.edu/urn-3:HUL.InstRepos:11744438, 2014.

Longo, M., Keller, M., dos Santos, M. N., Leitold, V., Pinagé, E. R., Baccini, A., Saatchi, S., Nogueira, E. M., Batistella, M., and Morton, D. C.: Aboveground biomass variability across intact and degraded forests in the Brazilian Amazon, Global Biogeochem. Cycles, 30, 1639-1660, https://doi.org/10.1002/2016GB005465, 2016.

Longo, M., Knox, R. G., Medvigy, D. M., Levine, N. M., Dietze, M. C., Kim, Y., Swann, A. L. S., Zhang, K., Rollinson, C. R., Bras, R. L., Wofsy, S. C., and Moorcroft, P. R.: The biophysics, ecology, and biogeochemistry of functionally diverse, vertically- and horizontallyheterogeneous ecosystems: the Ecosystem Demography Model, version 2.2 - Part 1: Model description, manuscript in review for Geosci. Model Dev., 2019.

Malhi, Y., Aragão, L. E. O. C., Galbraith, D., Huntingford, C., Fisher, R., Zelazowski, P., Sitch, S., McSweeney, C., and Meir, P.: Exploring the likelihood and mechanism of a climate-change-induced dieback of the Amazon rainforest, Proc. Natl. Acad. Sci. U. S. A., 106, 20 610-20 615, https://doi.org/10.1073/pnas.0804619106, 2009a.

Malhi, Y., Aragão, L. E. O. C., Metcalfe, D. B., Paiva, R., Quesada, C. A., Almeida, S., Anderson, L. O., Brando, P., Chambers, J. Q., da Costa, A. L., Hutyra, L. R., Oliveira, P., Patino, S., Pyle, E. H., Robertson, A. L., and Teixeira, L. M.: Comprehensive assessment of carbon productivity, allocation and storage in three Amazonian forests, Glob. Change Biol., 15, 1255-1274, https://doi.org/10.1111/j.13652486.2008.01780.x, 2009b.

Malhi, Y., Saatchi, S. S., Girardin, C., and Aragão, L. E. O. C.: The production, storage, and flow of carbon in Amazonian forests, in: Amazonia and Global Change, edited by Keller, M., Bustamante, M., Gash, J., and Silva Dias, P. L., vol. 186 of Geophysical Monograph, chap. 22, pp. 355-372, American Geophysical Union, Washington, DC, USA, https://doi.org/10.1029/2008GM000733, 2009c.

Matheny, A. M., Bohrer, G., Stoy, P. C., Baker, I., Black, A., Desai, A. R., Dietze, M., Gough, C., Ivanov, V., Jassal, P., Novick, K., Schäfer, K., and Verbeeck, H.: Characterizing the diurnal patterns of errors in the prediction of evapotranspiration by several land-surface models: an NACP analysis, J. Geophys. Res.-Biogeosci., 119, 1458-1473, https://doi.org/10.1002/2014JG002623, 2014.

McWilliam, A.-L. C., Roberts, J. M., Cabral, O. M. R., Leitão, M. V. B. R., da Costa, A. C. L., Maitelli, G. T., and Zamparoni, C. A. G. P.: Leaf Area Index and Above-Ground Biomass of terra firme Rain Forest and Adjacent Clearings in Amazonia, Funct. Ecol., 7, 310-317, https://doi.org/10.2307/2390210, 1993.

Medvigy, D. and Moorcroft, P. R.: Predicting ecosystem dynamics at regional scales: an evaluation of a terrestrial biosphere model for the forests of northeastern North America, Philos. Trans. R. Soc. B-Biol. Sci., 367, 222-235, https://doi.org/10.1098/rstb.2011.0253, 2012.

Medvigy, D., Jeong, S.-J., Clark, K. L., Skowronski, N. S., and Schäfer, K. V. R.: Effects of seasonal variation of photosynthetic capacity on the carbon fluxes of a temperate deciduous forest, J. Geophys. Res.-Biogeosci., 118, 1703-1714, https://doi.org/10.1002/2013JG002421, 2013.

Medvigy, D. M., Wofsy, S. C., Munger, J. W., Hollinger, D. Y., and Moorcroft, P. R.: Mechanistic scaling of ecosystem function and dynamics in space and time: Ecosystem Demography model version 2, J. Geophys. Res.-Biogeosci., 114, G01002, https://doi.org/10.1029/2008JG000812, 2009.

Mercado, L. M., Huntingford, C., Gash, J. H. C., Cox, P. M., and Jogireddy, V.: Improving the representation of radiation interception and photosynthesis for climate model applications, Tellus B, 59, 553-565, https://doi.org/10.1111/j.1600-0889.2007.00256.x, 2007.

Mercado, L. M., Bellouin, N., Sitch, S., Boucher, O., Huntingford, C., Wild, M., and Cox, P. M.: Impact of changes in diffuse radiation on the global land carbon sink, Nature, 458, 1014-1017, https://doi.org/10.1038/nature07949, 2009. 
Geosci. Model Dev. Discuss., https://doi.org/10.5194/gmd-2019-71

Manuscript under review for journal Geosci. Model Dev.

Discussion started: 28 March 2019

(c) Author(s) 2019. CC BY 4.0 License.

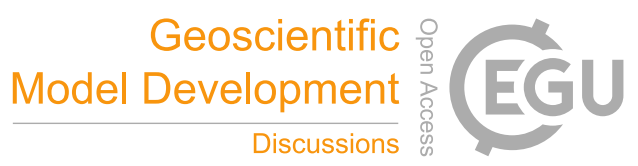

(c) (i)

Miller, A. D., Dietze, M. C., DeLucia, E. H., and Anderson-Teixeira, K. J.: Alteration of forest succession and carbon cycling under elevated $\mathrm{CO}_{2}$, Glob. Change Biol., 22, 351-363, https://doi.org/10.1111/gcb.13077, 2016.

Moorcroft, P. R.: Recent advances in ecosystem-atmosphere interactions: an ecological perspective, Proc. R. Soc. Lond. B-Biol. Sci., 270, 1215-1227, https://doi.org/10.1098/rspb.2002.2251, 2003.

5 Moorcroft, P. R.: How close are we to a predictive science of the biosphere?, Trends Ecol. Evol., 21, 400-407, https://doi.org/10.1016/j.tree.2006.04.009, 2006.

Moorcroft, P. R., Hurtt, G. C., and Pacala, S. W.: A method for scaling vegetation dynamics: The Ecosystem Demography model (ED), Ecol. Monogr., 71, 557-586, https://doi.org/10.1890/0012-9615(2001)071[0557:AMFSVD]2.0.CO;2, 2001.

Mori, A. S., Furukawa, T., and Sasaki, T.: Response diversity determines the resilience of ecosystems to environmental change, Biol. Rev., 88, 349-364, https://doi.org/10.1111/brv.12004, 2013

Morton, D. C., Le Page, Y., DeFries, R. S., Collatz, G. J., and Hurtt, G. C.: Understorey fire frequency and the fate of burned forests in southern Amazonia, Philos. Trans. R. Soc. B-Biol. Sci., 368, 20120 163, https://doi.org/10.1098/rstb.2012.0163, 2013.

Morton, D. C., Rubio, J., Cook, B. D., Gastellu-Etchegorry, J.-P., Longo, M., Choi, H., Hunter, M. O., and Keller, M.: Amazon forest structure generates diurnal and seasonal variability in light utilization, Biogeosciences, 12, 2195-2206, https://doi.org/10.5194/bg-13-2195-2016, 2016.

Nepstad, D. C., Moutinho, P., Dias-Filho, M. B., Davidson, E., Cardinot, G., Markewitz, D., Figueiredo, R., Vianna, N., Chambers, J., Ray, D., Guerreiros, J. B., Lefebvre, P., Sternberg, L., Moreira, M., Barros, L., Ishida, F. Y., Tohlver, I., Belk, E., Kalif, K., and Schwalbe, K.: The effects of partial throughfall exclusion on canopy processes, aboveground production, and biogeochemistry of an Amazon forest, J. Geophys. Res.-Atmos., 107, 8085, https://doi.org/10.1029/2001JD000360, 2002.

Phillips, O. L., Baker, T. R., Arroyo, L., Higuchi, N., Killeen, T. J., Laurance, W. F., Lewis, S. L., Lloyd, J., Malhi, Y., Monteagudo, A., Neill, D. A., Núñez Vargas, P., Silva, J. N. M., Terborgh, J., Vásquez Martínez, R., Alexiades, M., Almeida, S., Brown, S., Chave, J., Comiskey, J. A., Czimczik, C. I., Di Fiore, A., Erwin, T., Kuebler, C., Laurance, S. G., Nascimento, H. E. M., Olivier, J., Palacios, W., Patiño, S., Pitman, N. C. A., Quesada, C. A., Saldias, M., Torres Lezama, A., and Vinceti, B.: Pattern and process in Amazon tree turnover, 1976-2001, Philos. Trans. R. Soc. B-Biol. Sci., 359, 381-407, https://doi.org/10.1098/rstb.2003.1438, 2004.

Purves, D. W., Lichstein, J. W., Strigul, N., and Pacala, S. W.: Predicting and understanding forest dynamics using a simple tractable model, Proc. Natl. Acad. Sci. U. S. A., 105, 17 018-17 022, https://doi.org/10.1073/pnas.0807754105, 2008.

Pyle, E. H., Santoni, G. W., Nascimento, H. E. M., Hutyra, L. R., Vieira, S., Curran, D. J., van Haren, J., Saleska, S. R., Chow, V. Y., Carmago, P. B., Laurance, W. F., and Wofsy, S. C.: Dynamics of carbon, biomass, and structure in two Amazonian forests, J. Geophys. Res.-Biogeosci., 113, G00B08, https://doi.org/10.1029/2007JG000592, 2008.

Quesada, C. A., Lloyd, J., Anderson, L. O., Fyllas, N. M., Schwarz, M., and Czimczik, C. I.: Soils of Amazonia with particular reference to the RAINFOR sites, Biogeosciences, 8, 1415-1440, https://doi.org/10.5194/bg-8-1415-2011, 2011.

Quesada, C. A., Phillips, O. L., Schwarz, M., Czimczik, C. I., Baker, T. R., Patiño, S., Fyllas, N. M., Hodnett, M. G., Herrera, R., Almeida, S., Alvarez Dávila, E., Arneth, A., Arroyo, L., Chao, K. J., Dezzeo, N., Erwin, T., di Fiore, A., Higuchi, N., Honorio Coronado, E., Jimenez, E. M., Killeen, T., Lezama, A. T., Lloyd, G., López-González, G., Luizão, F. J., Malhi, Y., Monteagudo, A., Neill, D. A., Núñez Vargas, P., Paiva, R., Peacock, J., Peñuela, M. C., Peña Cruz, A., Pitman, N., Priante Filho, N., Prieto, A., Ramírez, H., Rudas, A., Salomão, R., Santos, A. J. B., Schmerler, J., Silva, N., Silveira, M., Vásquez, R., Vieira, I., Terborgh, J., and Lloyd, J.: Basin-wide variations in Amazon forest structure and function are mediated by both soils and climate, Biogeosciences, 9, 2203-2246, https://doi.org/10.5194/bg-9-2203$2012,2012$. 
Geosci. Model Dev. Discuss., https://doi.org/10.5194/gmd-2019-71

Manuscript under review for journal Geosci. Model Dev.

Discussion started: 28 March 2019

(c) Author(s) 2019. CC BY 4.0 License.

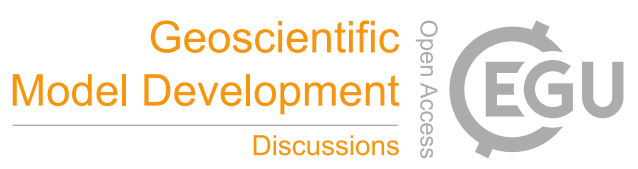

(c) (i)

Raczka, B., Dietze, M. C., Serbin, S. P., and Davis, K. J.: What Limits Predictive Certainty of Long-Term Carbon Uptake?, J. Geophys. Res.-Biogeosci., 123, 3570-3588, https://doi.org/10.1029/2018JG004504, 2018.

Rappaport, D., Morton, D., Longo, M., Keller, M., Dubayah, R., and dos-Santos, M. N.: Quantifying long-term changes in carbon stocks and forest structure from Amazon forest degradation, Environ. Res. Lett., 13, 065 013, https://doi.org/10.1088/1748-9326/aac331, 2018.

5 Restrepo-Coupe, N., Da Rocha, H. R., Christoffersen, B., de Araújo, A. C., Borma, L. S., Cabral, O. M., de Camargo, P. B., da Costa, A. C. L., Fitzjarrald, D. R., Goulden, M. L., Hutyra, L. R., Kruijt, B., Maia, J. M. F., Malhi, Y., Manzi, A. O., Miller, S. D., Nobre, A. D., von Randow, C., de Sá, Leonardo D. Sakai, R. K., Tota, J., Wofsy, S. C., Zanchi, F. B., and Saleska, S. R.: What drives the seasonality of productivity across the Amazon basin? A cross-site analysis of eddy flux tower measurements from the Brasil flux network, Agric. For. Meteorol., 182-183, 128-144, https://doi.org/10.1016/j.agrformet.2013.04.031, 2013.

Restrepo-Coupe, N., Levine, N. M., Christoffersen, B. O., Albert, L. P., Wu, J., Costa, M. H., Galbraith, D., Imbuzeiro, H., Martins, G., de Araújo, A. C., Malhi, Y. S., Zeng, X., Moorcroft, P., and Saleska, S. R.: Do dynamic global vegetation models capture the seasonality of carbon fluxes in the Amazon basin? A data-model intercomparison, Glob. Change Biol., 23, 191-208, https://doi.org/10.1111/gcb.13442, 2017.

Rollinson, C. R., Liu, Y., Raiho, A., Moore, D. J. P., McLachlan, J., Bishop, D. A., Dye, A., Matthes, J. H., Hessl, A., Hickler, T., Pederson, N., Poulter, B., Quaife, T., Schaefer, K., Steinkamp, J., and Dietze, M. C.: Emergent climate and $\mathrm{CO}_{2}$ sensitivities of net primary productivity in ecosystem models do not agree with empirical data in temperate forests of eastern North America, Glob. Change Biol., 23, 2755-2767, https://doi.org/10.1111/gcb.13626, https://onlinelibrary.wiley.com/doi/abs/10.1111/gcb.13626, 2017.

Rowland, L., Hill, T. C., Stahl, C., Siebicke, L., Burban, B., Zaragoza-Castells, J., Ponton, S., Bonal, D., Meir, P., and Williams, M.: Evidence for strong seasonality in the carbon storage and carbon use efficiency of an Amazonian forest, Glob. Change Biol., 20, 979-991, https://doi.org/10.1111/gcb.12375, 2014.

Saatchi, S. S., Harris, N. L., Brown, S., Lefsky, M., Mitchard, E. T. A., Salas, W., Zutta, B. R., Buermann, W., Lewis, S. L., Hagen, S., Petrova, S., White, L., Silman, M., and Morel, A.: Benchmark map of forest carbon stocks in tropical regions across three continents, Proc. Natl. Acad. Sci. U. S. A., 108, 9899-9904, https://doi.org/10.1073/pnas.1019576108, 2011.

Saxton, K. E. and Rawls, W. J.: Soil Water Characteristic Estimates by Texture and Organic Matter for Hydrologic Solutions, Soil Sci. Soc. Am. J., 70, 1569-1578, https://doi.org/10.2136/sssaj2005.0117, 2006.

Schenk, H. J., Espino, S., Goedhart, C. M., Nordenstahl, M., Cabrera, H. I. M., and Jones, C. S.: Hydraulic integration and shrub growth form linked across continental aridity gradients, Proc. Natl. Acad. Sci. U. S. A., 105, 11 248-11 253, https://doi.org/10.1073/pnas.0804294105, 2008.

Schimel, D., Pavlick, R., Fisher, J. B., Asner, G. P., Saatchi, S., Townsend, P., Miller, C., Frankenberg, C., Hibbard, K., and Cox, P.: Observing terrestrial ecosystems and the carbon cycle from space, Glob. Change Biol., 21, 1762-1776, https://doi.org/10.1111/gcb.12822, 2015.

Sheffield, J., Goteti, G., and Wood, E. F.: Development of a 50-Year High-Resolution Global Dataset of Meteorological Forcings for Land Surface Modeling, J. Climate, 19, 3088-3111, https://doi.org/10.1175/JCLI3790.1, 2006.

Simon, E., Lehmann, B., Ammann, C., Ganzeveld, L., Rummel, U., Meixner, F., Nobre, A., Araújo, A., and Kesselmeier, J.: Lagrangian dispersion of ${ }^{222} \mathrm{Rn}, \mathrm{H}_{2} \mathrm{O}$ and $\mathrm{CO}_{2}$ within Amazonian rain forest, Agric. For. Meteorol., 132, 286-304, https://doi.org/10.1016/j.agrformet.2005.08.004, 2005.

Soares-Filho, B. S., Nepstad, D. C., Curran, L. M., Cerqueira, G. C., Garcia, R. A., Ramos, C. A., Voll, E., McDonald, A., Lefebvre, P., and Schlesinger, P.: Modelling conservation in the Amazon basin., Nature, 440, 520 - 523, https://doi.org/doi:10.1038/nature04389, 2006. 
Geosci. Model Dev. Discuss., https://doi.org/10.5194/gmd-2019-71

Manuscript under review for journal Geosci. Model Dev.

Discussion started: 28 March 2019

(c) Author(s) 2019. CC BY 4.0 License.

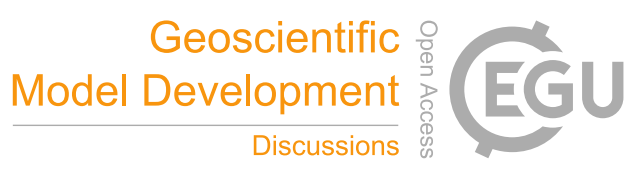

(c) (i)

Stahl, C.: Variations saisonnières des flux de $\mathrm{CO}_{2}$ et $\mathrm{H}_{2} \mathrm{O}$ au niveau des feuilles et des troncs des arbres de la canopée en forêt tropicale humide guyanaise, Ph.d. thesis, Université Henri Poincaré de Nancy, Nancy, Lorraine, France, http://www.theses.fr/2010NAN10049, in French, 2010.

Stavros, E. N., Schimel, D., Pavlick, R., Serbin, S., Swann, A., Duncanson, L., Fisher, J. B., Fassnacht, F., Ustin, S., Dubayah, R., Schweiger, A., and Wennberg, P.: ISS observations offer insights into plant function, Nature Ecol. Evol., 1, 0194, https://doi.org/10.1038/s41559-0170194, 2017.

Stoy, P. C., Mauder, M., Foken, T., Marcolla, B., Boegh, E., Ibrom, A., Arain, M. A., Arneth, A., Aurela, M., Bernhofer, C., Cescatti, A., Dellwik, E., Duce, P., Gianelle, D., van Gorsel, E., Kiely, G., Knohl, A., Margolis, H., McCaughey, H., Merbold, L., Montagnani, L., Papale, D., Reichstein, M., Saunders, M., Serrano-Ortiz, P., Sottocornola, M., Spano, D., Vaccari, F., and Varlagin, A.: A data-driven analysis of energy balance closure across FLUXNET research sites: The role of landscape scale heterogeneity, Agric. For. Meteorol., 171-172, 137-152, https://doi.org/http://dx.doi.org/10.1016/j.agrformet.2012.11.004, 2013.

Tempel, P., Batjes, N. H., and van Engelen, V. W. P.: IGBP-DIS soil data set for pedotransfer function development, Working paper and prepint 96/05, International Soil Reference and Information Centre (ISRIC), Wageningen, Netherlands, http://gcmd.nasa.gov/r/d/\%5BGCMD\% 5DISRIC_IGBP-DIS-PTFset, 1996.

ter Steege, H., Pitman, N. C. A., Phillips, O. L., Chave, J., Sabatier, D., Duque, A., Molino, J.-F., Prevost, M.-F., Spichiger, R., Castellanos, H., von Hildebrand, P., and Vasquez, R.: Continental-scale patterns of canopy tree composition and function across Amazonia, Nature, 443, 444-447, https://doi.org/10.1038/nature05134, 2006.

Tilman, D.: Biodiversity: Population Versus Ecosystem Stability, Ecology, 77, 350-363, https://doi.org/10.2307/2265614, 1996.

Tobón Marin, C., Bouten, W., and Sevink, J.: Gross rainfall and its partitioning into throughfall, stemflow and evaporation of intercepted water in four forest ecosystems in western Amazonia, J. Hydrol., 237, 40-57, https://doi.org/10.1016/S0022-1694(00)00301-2, 2000.

Tomasella, J., Nobre, C. A., Gash, J. H. C., Shuttleworth, W. J., Roberts, J. M., Cabral, O. M., and Fisch, G. F.: Pre-LBA Anglo-BRazilian Amazonian Climate Observation Study (ABRACOS) Data, Data set, Oak Ridge National Laboratory Distributed Active Archive Center, Oak Ridge, Tennessee, U.S.A., https://doi.org/10.3334/ORNLDAAC/899, 2008.

Toomey, M., Roberts, D., and Nelson, B.: The influence of epiphylls on remote sensing of humid forests, Remote Sens. Environ., 113, 1787-1798, https://doi.org/10.1016/j.rse.2009.04.002, 2009.

Tóta, J., Fitzjarrald, D. R., Staebler, R. M., Sakai, R. K., Moraes, O. M. M., Acevedo, O. C., Wofsy, S. C., and Manzi, A. O.: Amazon rain forest subcanopy flow and the carbon budget: Santarém LBA-ECO site, J. Geophys. Res.-Biogeosci., 113, G00B02, https://doi.org/10.1029/2007JG000597, 2008.

TRMM: Tropical Rainfall Measuring Mission (TRMM) (TMPA/3B43) Rainfall Estimate L3 1 month $0.25^{\circ} \times 0.25^{\circ}$ V7, https://doi.org/10.5067/TRMM/TMPA/MONTH/7, https://disc.gsfc.nasa.gov, 2011.

Trugman, A. T., Medvigy, D., Hoffmann, W. A., and Pellegrini, A. F. A.: Sensitivity of woody carbon stocks to bark investment strategy in Neotropical savannas and forests, Biogeosciences, 15, 233-243, https://doi.org/10.5194/bg-15-233-2018, 2018.

Tyukavina, A., Hansen, M. C., Potapov, P. V., Stehman, S. V., Smith-Rodriguez, K., Okpa, C., and Aguilar, R.: Types and rates of forest disturbance in Brazilian Legal Amazon, 2000-2013, Sci. Adv., 3, e1601 047, https://doi.org/10.1126/sciadv.1601047, 2017.

Walker, A. P., Hanson, P. J., De Kauwe, M. G., Medlyn, B. E., Zaehle, S., Asao, S., Dietze, M., Hickler, T., Huntingford, C., Iversen, C. M., Jain, A., Lomas, M., Luo, Y., McCarthy, H., Parton, W. J., Prentice, I. C., Thornton, P. E., Wang, S., Wang, Y.-P., Warlind, D., Weng, E., Warren, J. M., Woodward, F. I., Oren, R., and Norby, R. J.: Comprehensive ecosystem model-data synthesis using multiple data sets at two 
Geosci. Model Dev. Discuss., https://doi.org/10.5194/gmd-2019-71

Manuscript under review for journal Geosci. Model Dev.

Discussion started: 28 March 2019

(c) Author(s) 2019. CC BY 4.0 License.

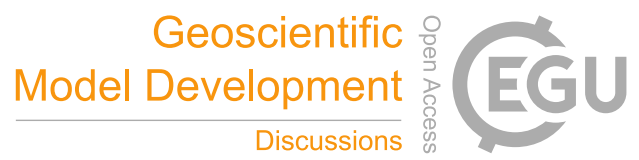

(c) (1)

temperate forest free-air $\mathrm{CO}_{2}$ enrichment experiments: Model performance at ambient $\mathrm{CO}_{2}$ concentration, J. Geophys. Res.-Biogeosci., 119, 937-964, https://doi.org/10.1002/2013JG002553, 2014.

Wehr, R., Munger, J. W., McManus, J. B., Nelson, D. D., Zahniser, M. S., Davidson, E. A., Wofsy, S. C., and Saleska, S. R.: Seasonality of temperate forest photosynthesis and daytime respiration, Nature, 534, 680-683, https://doi.org/10.1038/nature17966, 2016.

5 Wu, J., Albert, L. P., Lopes, A. P., Restrepo-Coupe, N., Hayek, M., Wiedemann, K. T., Guan, K., Stark, S. C., Christoffersen, B., Prohaska, N., Tavares, J. V., Marostica, S., Kobayashi, H., Ferreira, M. L., Campos, K. S., da Silva, R., Brando, P. M., Dye, D. G., Huxman, T. E., Huete, A. R., Nelson, B. W., and Saleska, S. R.: Leaf development and demography explain photosynthetic seasonality in Amazon evergreen forests, Science, 351, 972-976, https://doi.org/10.1126/science.aad5068, 2016.

Xu, X., Medvigy, D., Wright, S. J., Kitajima, K., Wu, J., Albert, L. P., Martins, G. A., Saleska, S. R., and Pacala, S. W.: Variations of leaf longevity in tropical moist forests predicted by a trait-driven carbon optimality model, Ecol. Lett., 20, 1097-1106, https://doi.org/10.1111/ele.12804, 2017.

Yan, K., Park, T., Yan, G., Chen, C., Yang, B., Liu, Z., Nemani, R. R., Knyazikhin, Y., and Myneni, R. B.: Evaluation of MODIS LAI/FPAR product Collection 6. Part I: consistency and improvements, Remote Sens., 8, 359, https://doi.org/10.3390/rs8050359, 2016. 